Supplementary Information

for

\title{
Fused hybrid linkers for metal-organic framework-derived bifunctional oxygen electrocatalysts
}

Kefeng Ping, ${ }^{\mathrm{a}}$ Alan Braschinsky, ${ }^{\mathrm{b}}$ Mahboob Alam, ${ }^{\mathrm{a}}$ Rohit Bhadoria, ${ }^{\mathrm{a}}$ Valdek Mikli, ${ }^{\mathrm{c}}$ Arvo Mere, ${ }^{\mathrm{c}}$ Jaan Aruväli, ${ }^{\mathrm{d}}$ Päärn Paiste, ${ }^{\mathrm{d}}$ Sergei Vlassov, ${ }^{\mathrm{e}}$ Mati Kook, ${ }^{\mathrm{e}}$ Mihkel Rähn, ${ }^{\mathrm{e}}$ Väino Sammelselg, ${ }^{\text {,ee Kaido }}$ Tammeveski, ${ }^{\mathrm{b}}$ Nadežda Kongi, ${ }^{\mathrm{b},{ }^{*}}$ and Pavel Starkov ${ }^{\mathrm{a}, *}$

${ }^{a}$ Department of Chemistry \& Biotechnology, Tallinn University of Technology, 12618 Tallinn, Estonia

${ }^{b}$ Institute of Chemistry, University of Tartu, 50411 Tartu, Estonia

${ }^{c}$ Department of Materials \& Environmental Technology, Tallinn University of Technology, 19086 Tallinn, Estonia

${ }^{d}$ Institute of Ecology and Earth Sciences, University of Tartu, 50411 Tartu, Estonia

e Institute of Physics, University of Tartu, 50411 Tartu, Estonia

*Corresponding authors. E-mail: nadezda.kongi@ut.ee; pavel.starkov@taltech.ee

Table of Contents

1. Additional Data $\quad$ S2

2. Methods $\quad \mathrm{S} 12$

3. Synthetic Procedures $\quad$ S14

4. References $\quad$ S16

5. NMR Spectra $\quad$ S18 

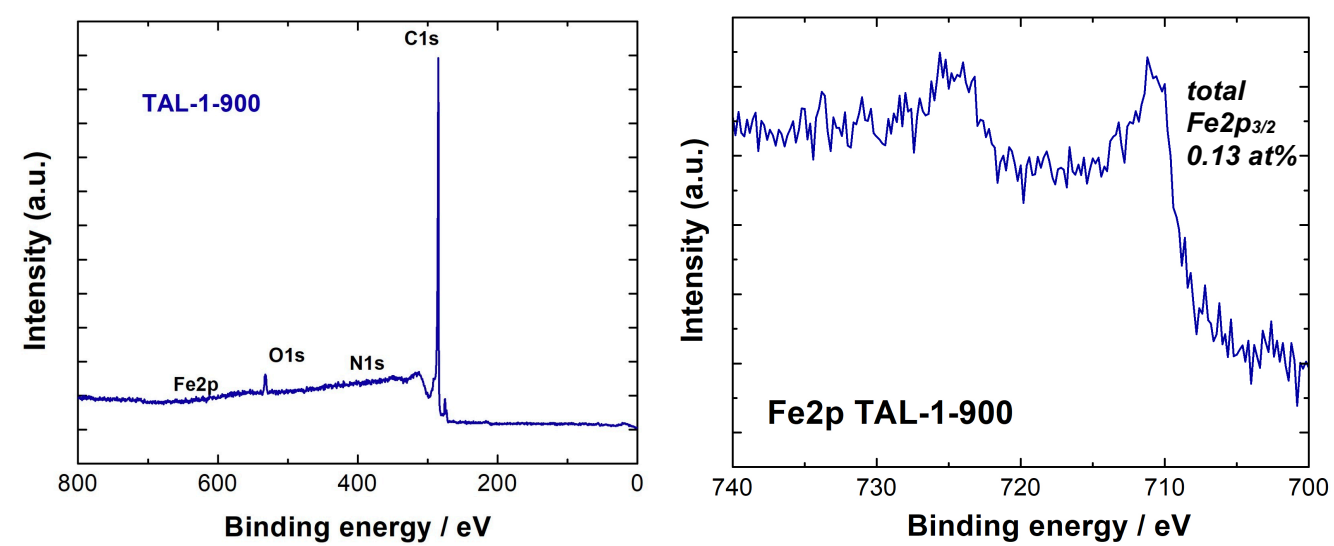

TAL-1-900
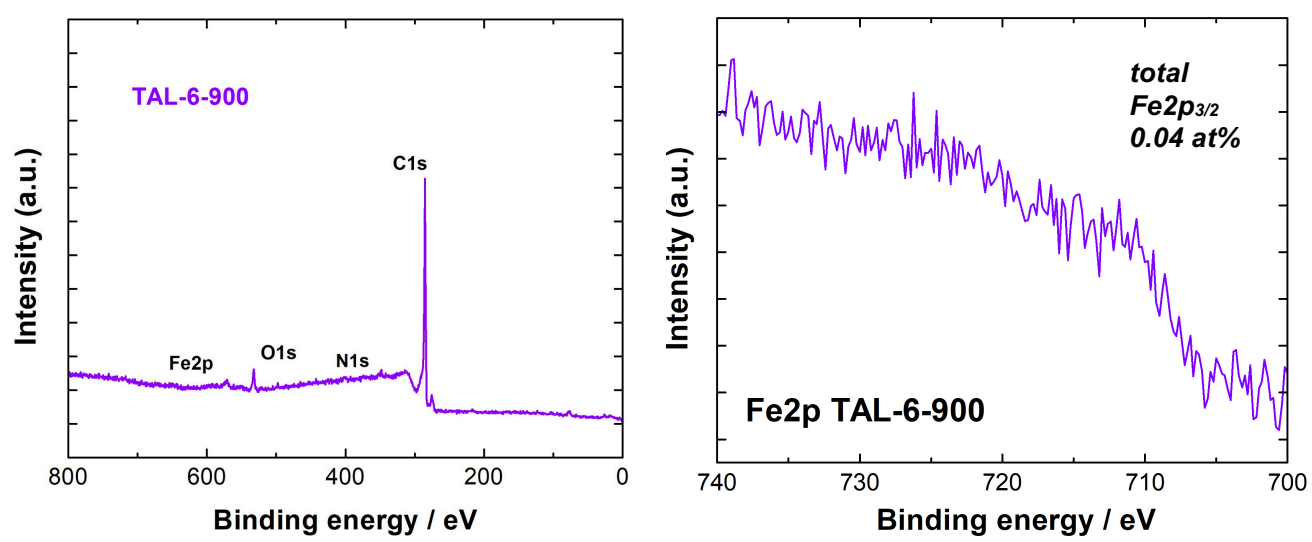

TAL-6-900
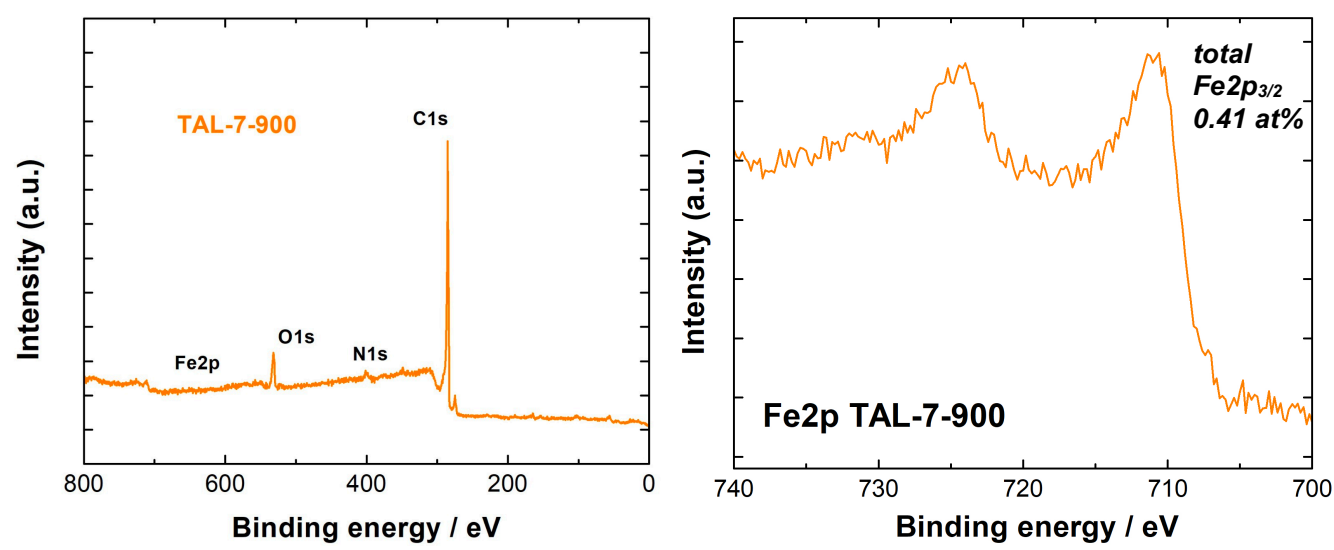

TAL-7-900

Figure S1. The XPS survey spectra and Fe2p core-level XPS spectra for TAL-X-900 materials

Table S1. Contents of iron in TAL-X derived catalysts confirmed by microwave plasma atomic emission spectroscopy (MP-AES)

\begin{tabular}{|c|c|c|}
\hline & Fe wt\% & $\mathbf{\pm}$ wt\% \\
\hline TAL-1-900 & 0.896 & 0.006 \\
\hline TAL-6-900 & 1.584 & 0.014 \\
\hline TAL-7-900 & 3.603 & 0.035 \\
\hline
\end{tabular}


Table S2. Contents of different nitrogen and carbon moieties found on the surface of the catalyst material, relative to the total nitrogen and carbon content in TAL-X-900 materials

\begin{tabular}{|c|c|c|c|c|c|c|}
\cline { 2 - 7 } \multicolumn{1}{c|}{} & $\begin{array}{c}\text { total } \mathbf{N} \\
\text { content } \\
\text { at\% }\end{array}$ & $\begin{array}{c}\mathbf{N}-\mathbf{O} \\
\%\end{array}$ & $\begin{array}{c}\text { graphitic N } \\
\%\end{array}$ & $\begin{array}{c}\text { pyrrolic N } \\
\%\end{array}$ & $\begin{array}{c}\mathbf{F e - N} \\
\%\end{array}$ & $\begin{array}{c}\text { pyridinic } \mathbf{N} \\
\%\end{array}$ \\
\hline TAL-1-900 & 0.6 & 0 & 5 & 37 & 26 & 32 \\
\hline TAL-6-900 & 0.4 & 10 & 9 & 30 & 24 & 27 \\
\hline TAL-7-900 & 1.0 & 1 & 4 & 52 & 5 & 38 \\
\hline
\end{tabular}

\begin{tabular}{|c|c|c|c|c|c|c|c|c|}
\hline & $\begin{array}{c}\text { total C } \\
\text { content } \\
\text { at } \%\end{array}$ & $\underset{\%}{\mathrm{C}-\mathrm{O}-\mathrm{C}, \mathrm{C}-\mathrm{OH}}$ & $\begin{array}{c}C=0 \\
\%\end{array}$ & $O-C=0 \%$ & $\begin{array}{c}\text { carbide } \\
\%\end{array}$ & $\begin{array}{c}\pi-\pi^{*} \\
\%\end{array}$ & $\begin{array}{l}s p^{2} \\
\%\end{array}$ & $\begin{array}{c}s p^{3} \\
\%\end{array}$ \\
\hline TAL-1-900 & 97.1 & 6 & 1 & 0 & 7 & 9 & 66 & 11 \\
\hline TAL-6-900 & 97.4 & 2 & 3 & 2 & 7 & 6 & 63 & 17 \\
\hline TAL-7-900 & 93.5 & 8 & 3 & 2 & 6 & 7 & 42 & 32 \\
\hline
\end{tabular}

Table S3. Contents of different nitrogen and carbon moieties found on the surface of the catalyst material, relative to the total nitrogen and carbon content in TAL-1 derived materials before and after acid etching

\begin{tabular}{|c|c|c|c|c|c|c|}
\cline { 2 - 7 } \multicolumn{1}{c|}{} & $\begin{array}{c}\text { total } \mathbf{N} \\
\text { content } \\
\text { at.\% }\end{array}$ & $\begin{array}{c}\mathbf{N - O} \\
\%\end{array}$ & $\begin{array}{c}\text { graphitic N } \\
\%\end{array}$ & $\begin{array}{c}\text { pyrrolic N } \\
\%\end{array}$ & $\begin{array}{c}\text { Fe-Nx } \\
\%\end{array}$ & $\begin{array}{c}\text { pyridinic } \mathbf{N} \\
\%\end{array}$ \\
\hline TAL-1 & 15.8 & 1 & 3 & 75 & 21 & 0 \\
\hline $\begin{array}{c}\text { TAL-1-900C } \\
\text { i.e. not leached }\end{array}$ & 1.7 & 6 & 5 & 39 & 26 & 24 \\
\hline $\begin{array}{c}\text { TAL-1-900 } \\
\text { i.e. acid leached }\end{array}$ & 0.6 & 0 & 5 & 37 & 26 & 32 \\
\hline
\end{tabular}

\begin{tabular}{|c|c|c|c|c|c|c|c|c|}
\cline { 2 - 9 } \multicolumn{1}{c|}{} & $\begin{array}{c}\text { total C } \\
\text { content } \\
\text { at.\% }\end{array}$ & $\begin{array}{c}\mathbf{C}-\mathbf{O}-\mathbf{C}, \boldsymbol{C}-\mathbf{O H} \\
\%\end{array}$ & $\begin{array}{c}\mathbf{C = O} \\
\%\end{array}$ & $\begin{array}{c}\mathbf{O}-\mathbf{C = O} \\
\%\end{array}$ & $\begin{array}{c}\text { carbide } \\
\%\end{array}$ & $\begin{array}{c}\pi-\pi^{*} \\
\%\end{array}$ & $\begin{array}{c}\mathbf{s p}^{2} \\
\%\end{array}$ & $\begin{array}{c}\mathbf{s p}^{3} \\
\%\end{array}$ \\
\hline TAL-1 & 63.0 & 34 & 14 & 5 & 0 & 4 & 7 & 36 \\
\hline $\begin{array}{c}\text { TAL-1-900C } \\
\text { i.e. not leached }\end{array}$ & 74.6 & 6 & 5 & 1 & 4 & 2 & 65 & 17 \\
\hline $\begin{array}{c}\text { TAL-1-900 } \\
\text { i.e. acid leached }\end{array}$ & 97.1 & 6 & 1 & 0 & 7 & 9 & 66 & 11 \\
\hline
\end{tabular}
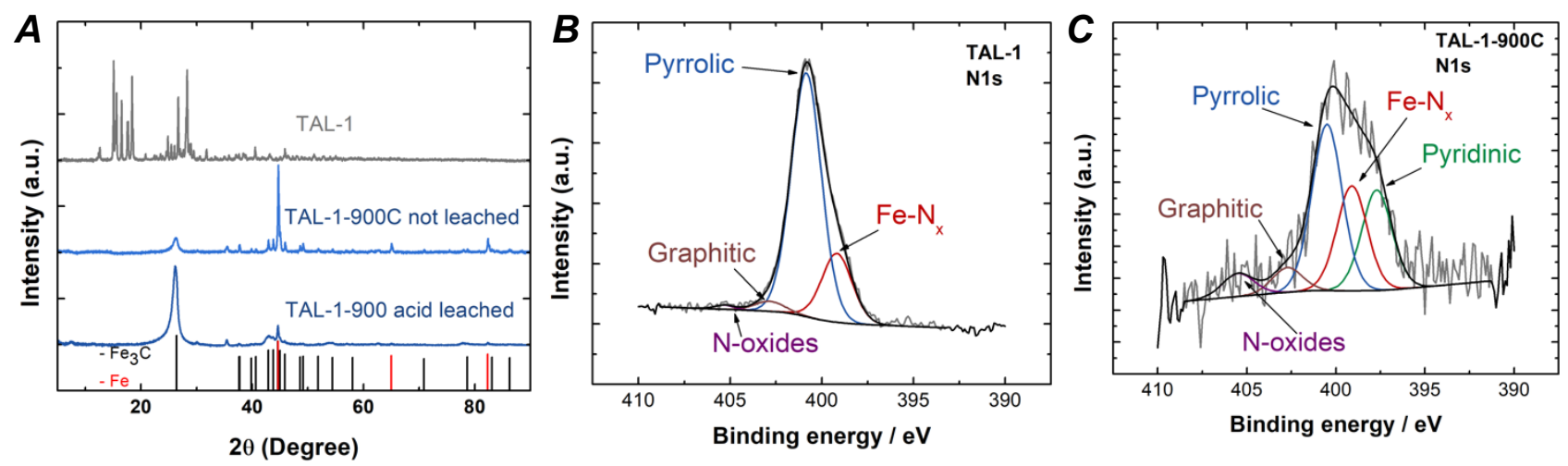

Figure S2. (a) PXRD patterns of TAL-1 derived catalysts. (b,c) XPS core-level spectra in the N1s region for TAL-1 and non-acid etched TAL-1-900C 

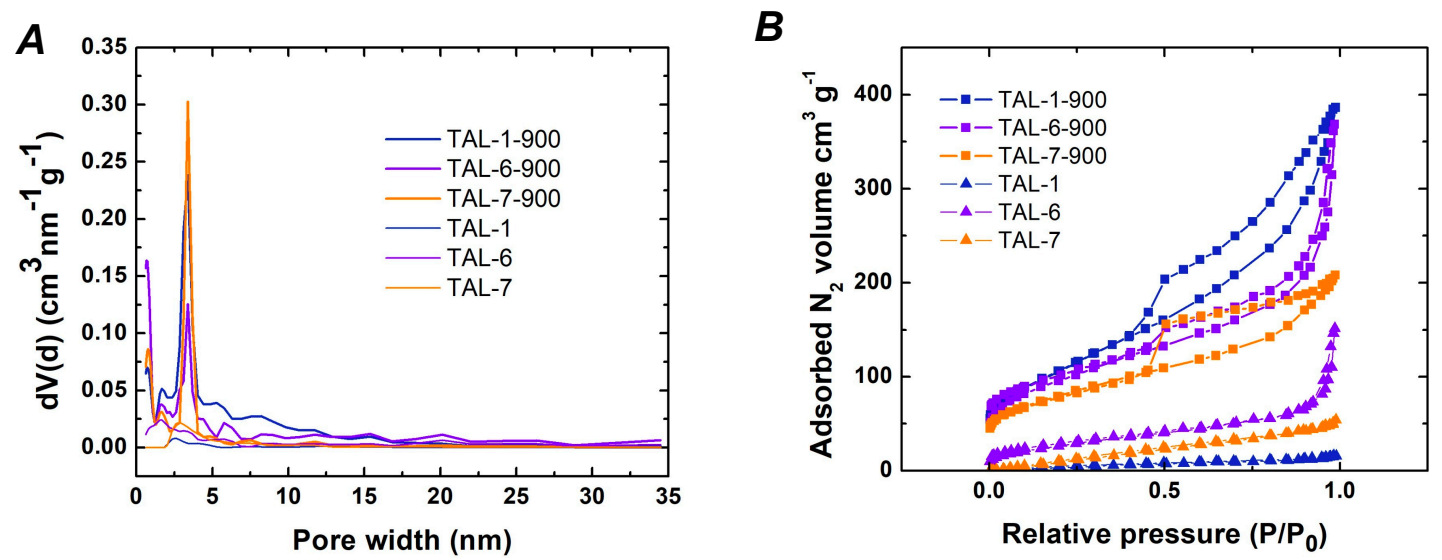

Figure S3. (a) Pore sizes in (b) dinitrogen adsorption/desorption by TAL-X-900 catalyst materials

Table S4. Specific surface area and porosity related parameters of TAL-X-900 catalyst materials derived from nitrogen physisorption analysis.

\begin{tabular}{|c|c|c|c|c|}
\hline catalyst & $S_{\text {BET }}\left(\boldsymbol{m}^{\mathbf{2}} \mathbf{g}^{-1}\right)$ & $S_{\text {DFT }}\left(\boldsymbol{m}^{\mathbf{2}} \mathbf{g}^{-1}\right)$ & $V_{\text {tot }}\left(\mathbf{c m}^{\mathbf{3}} \mathbf{g}^{-1}\right)$ & $\boldsymbol{V}_{\boldsymbol{\mu}}\left(\mathbf{c m}^{\mathbf{3}} \mathbf{g}^{-1}\right)$ \\
\hline TAL-1-900 & 380 & 345 & 0.541 & 0.073 \\
\hline TAL-6-900 & 344 & 363 & 0.43 & 0.11 \\
\hline TAL-7-900 & 282 & 262 & 0.3 & 0.07 \\
\hline TAL-1 & 23 & 10 & 0.022 & 0 \\
\hline TAL-6 & 97 & 84 & 0.15 & 0 \\
\hline TAL-7 & 105 & 32 & 0.07 & 0.03 \\
\hline
\end{tabular}

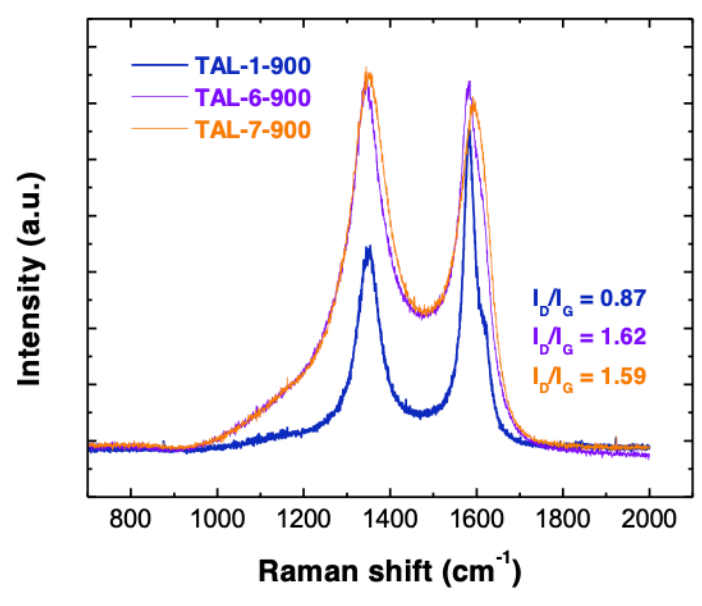

Figure S4. Raman spectra of TAL-X-900 catalyst materials. 

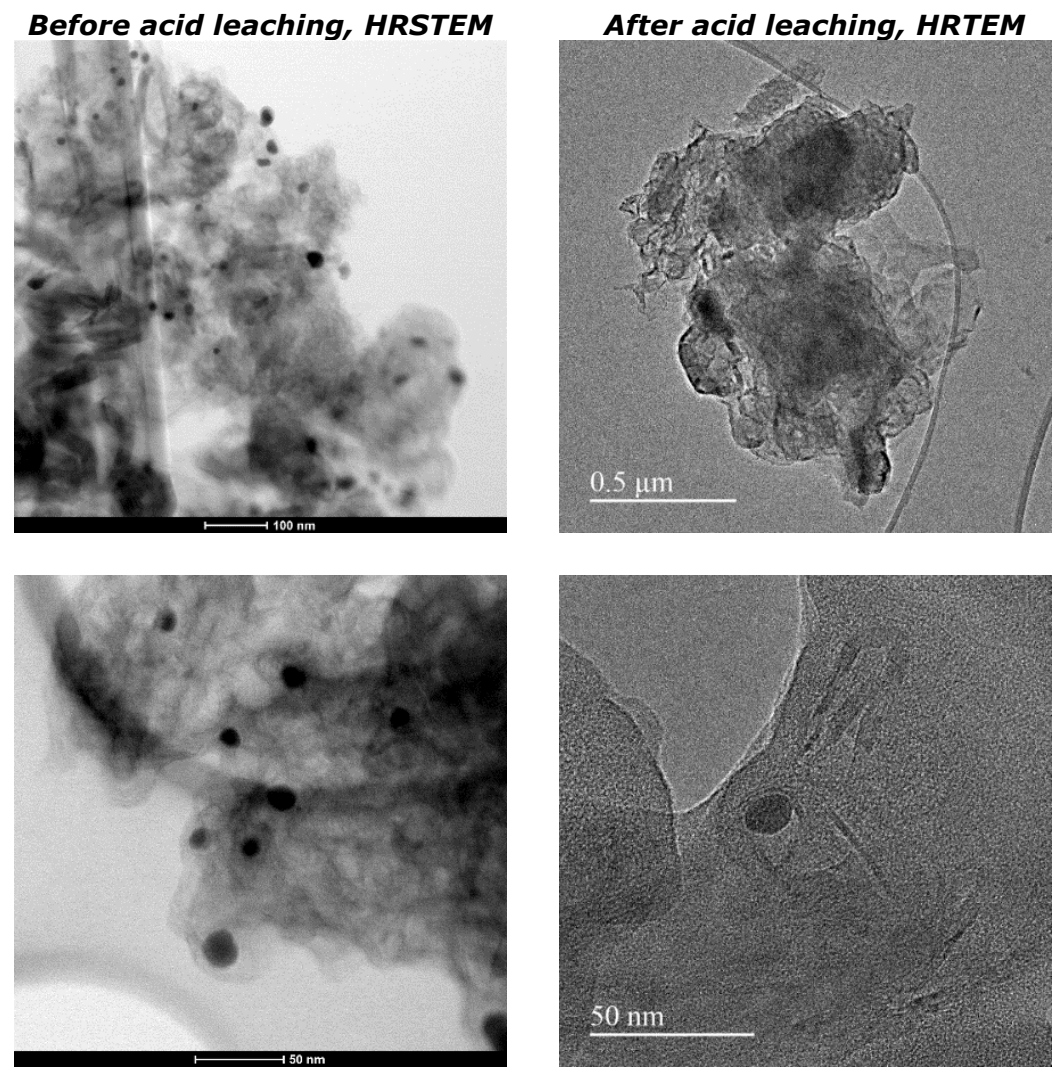

Figure S5. HRTEM micrographs for TAL-1-900 catalyst before and after acid etching
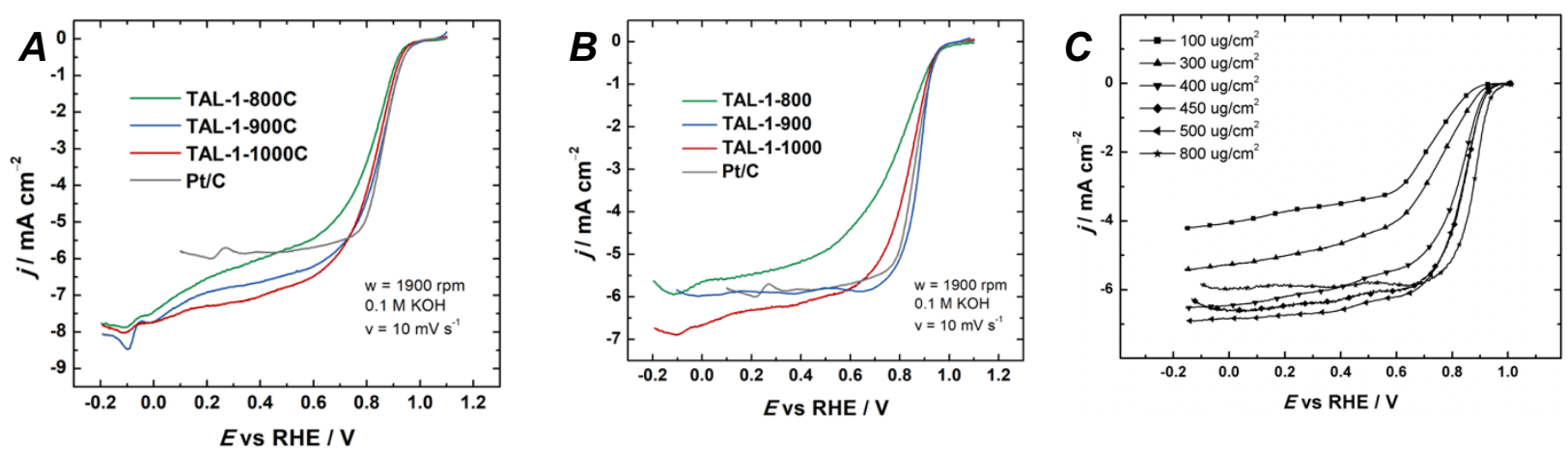

Figure S6. Comparison of RDE polarization curves for TAL-1-derived catalysts carbonized at different temperatures: (a) non-acid-leached vs. (b) acid-etched catalyst materials and (c) different catalyst loadings for TAL-1-900. 
A
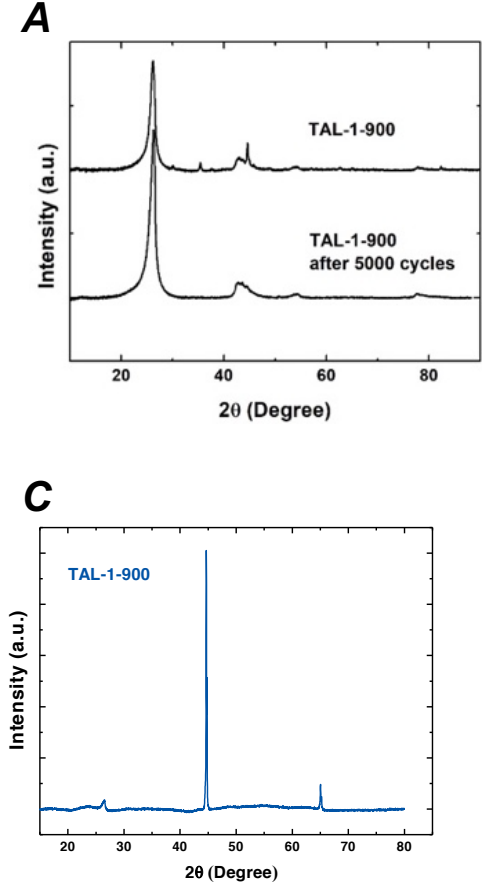

B
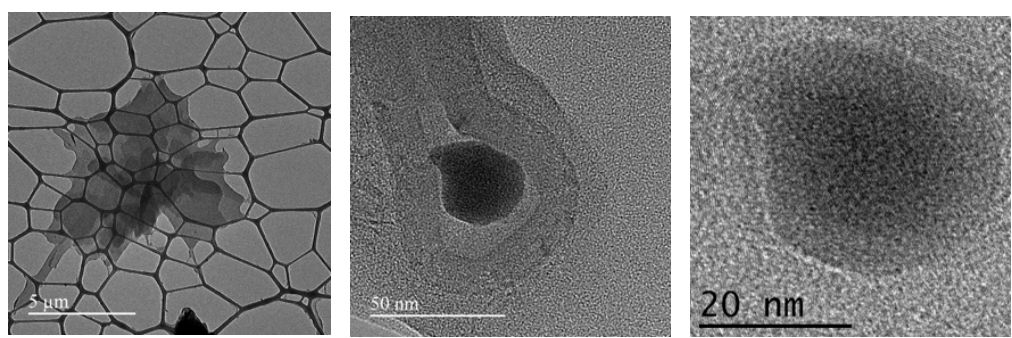

D
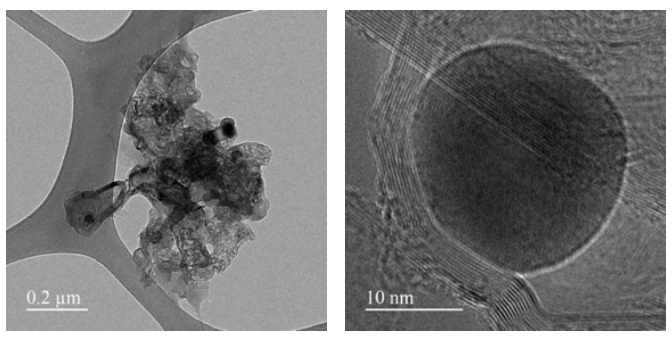

Figure S7. (a) PXRD patterns and (b) HRTEM micrographs of TAL-1-900 catalyst before and after accelerated stability test (ORR). (c) PXRD patterns and (d) HRTEM micrographs of TAL-1-900 catalyst after accelerated stability test (OER).

Table S5. Elemental (CHN) analysis of TAL-1 prepared from different metal/ligand ratios

\begin{tabular}{|c|c|c|c|}
\hline $\begin{array}{c}\text { starting } \\
\mathbf{M} / \mathbf{L}\end{array}$ & $\begin{array}{c}\text { carbon } \\
\boldsymbol{\%}\end{array}$ & $\begin{array}{c}\text { hydrogen } \\
\text { \% }\end{array}$ & $\begin{array}{c}\text { nitrogen } \\
\boldsymbol{\%}\end{array}$ \\
\hline $2: 1$ & 33.54 & 3.23 & 13.50 \\
\hline $1: 1$ & 36.31 & 3.18 & 14.16 \\
\hline $1: 2$ & 39.65 & 3.05 & 15.03 \\
\hline
\end{tabular}



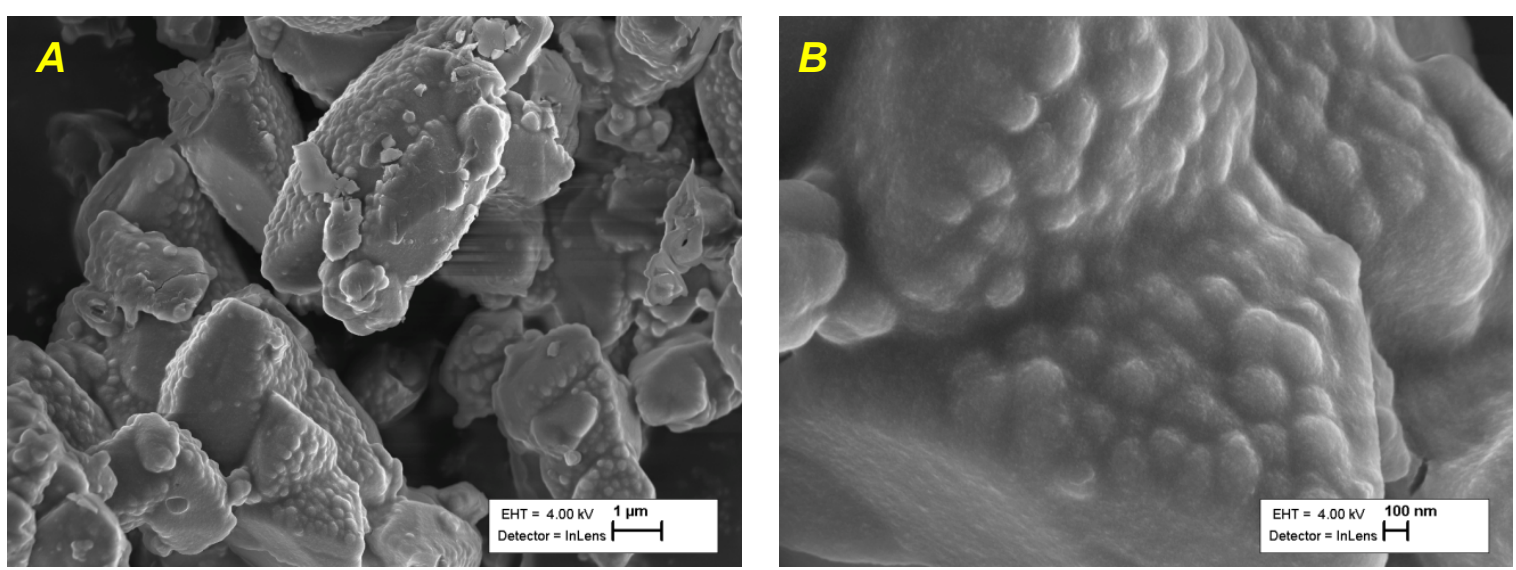

TAL-1
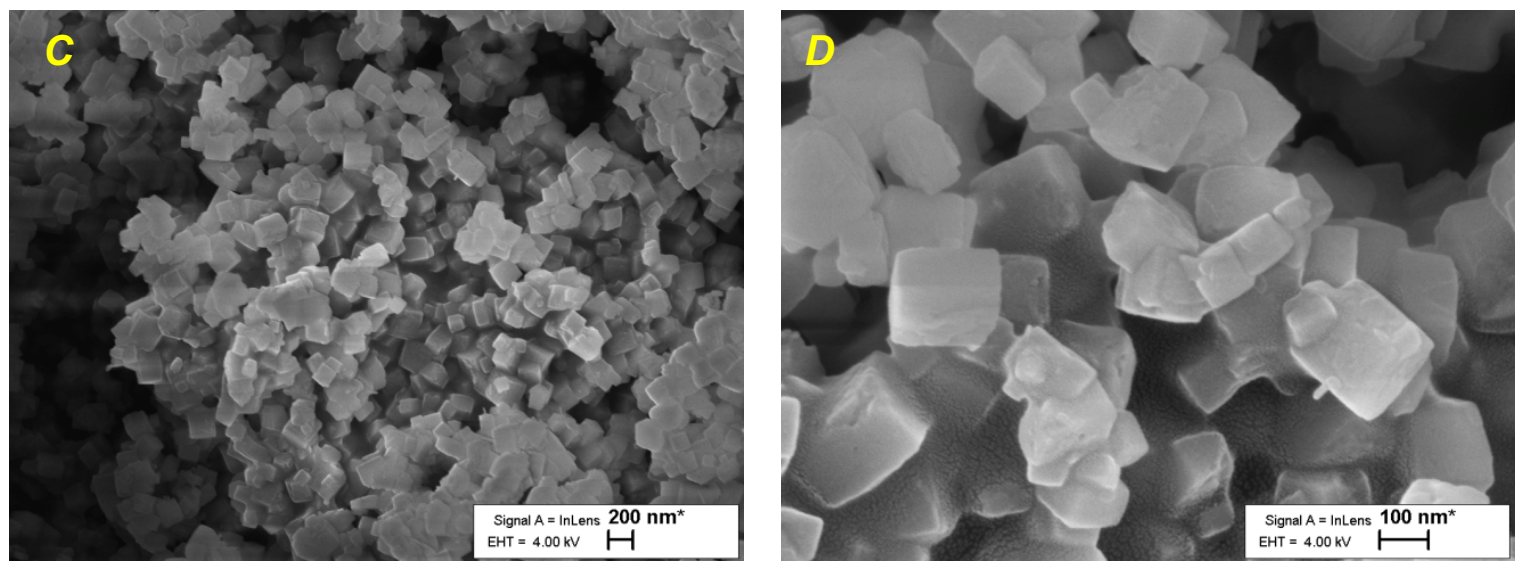

TAL-6
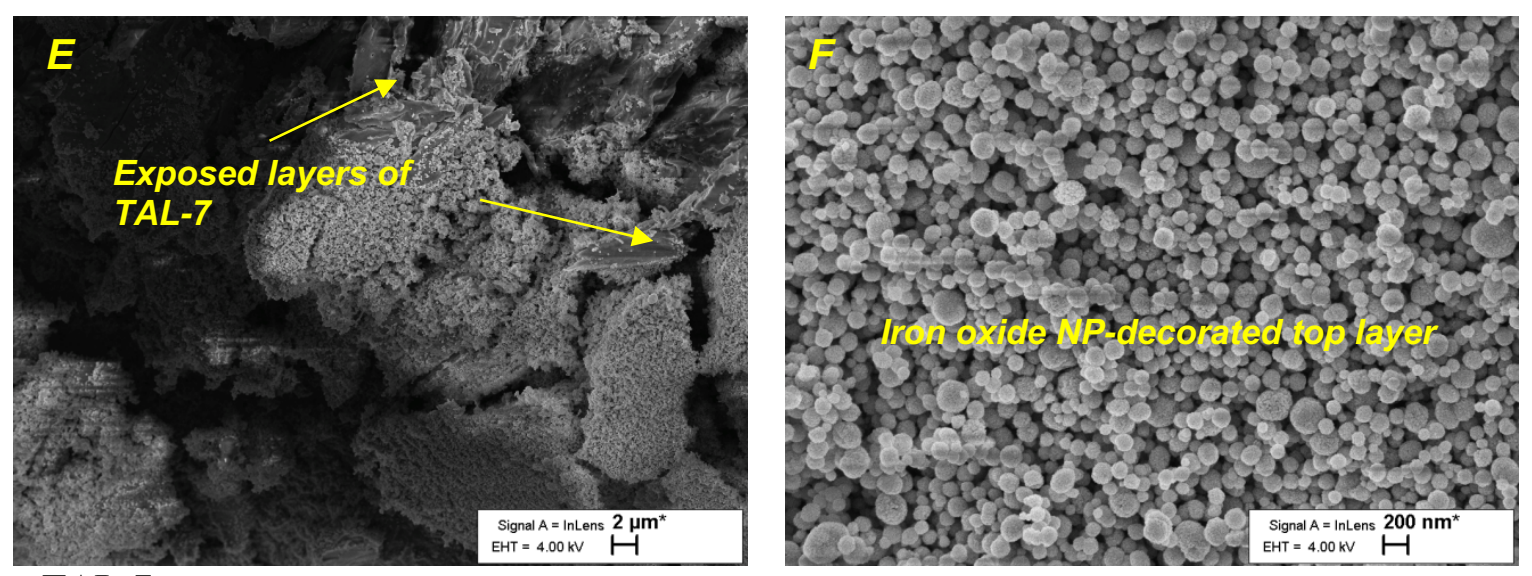

TAL-7

Figure S8. HRSEM images of TAL-1 (a,b), TAL-6 (c,d) and TAL-7 (e,f) 

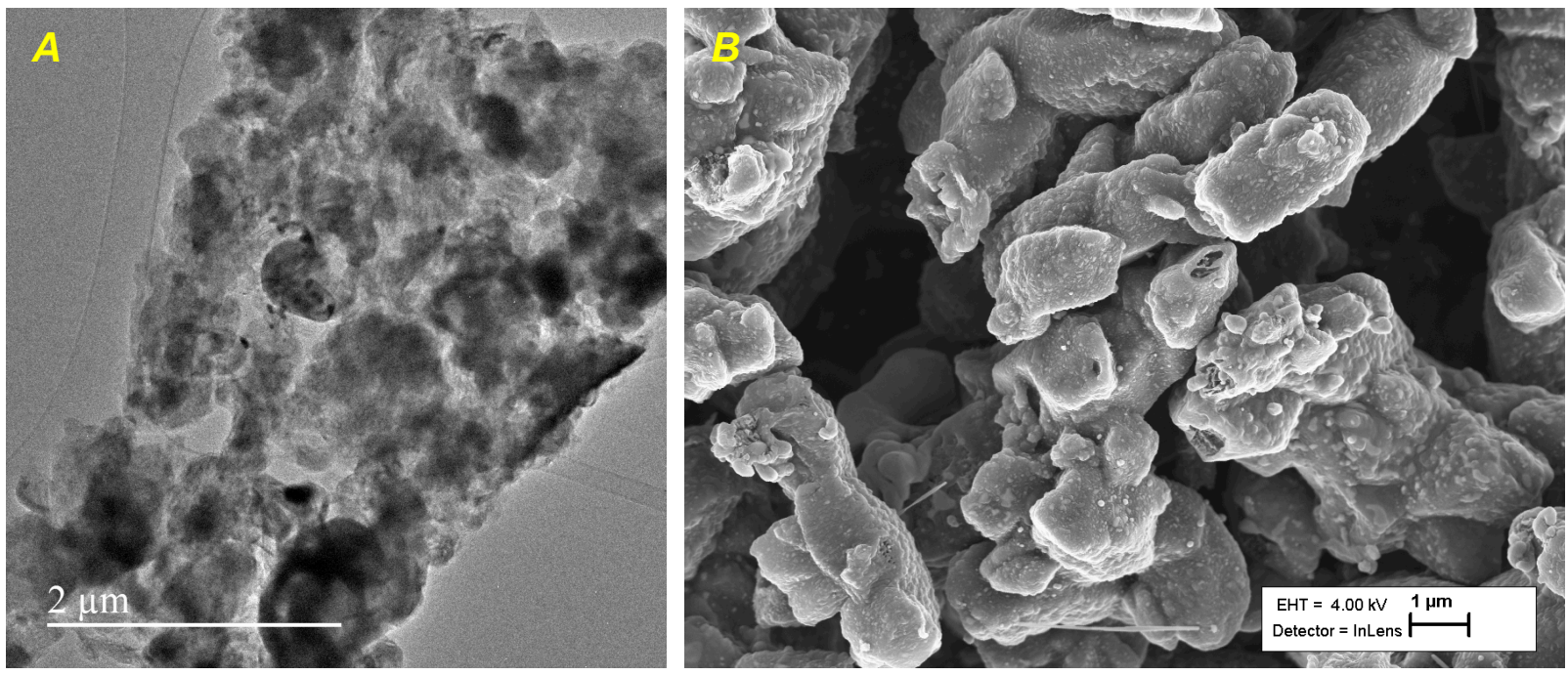

\section{TAL-1-900}
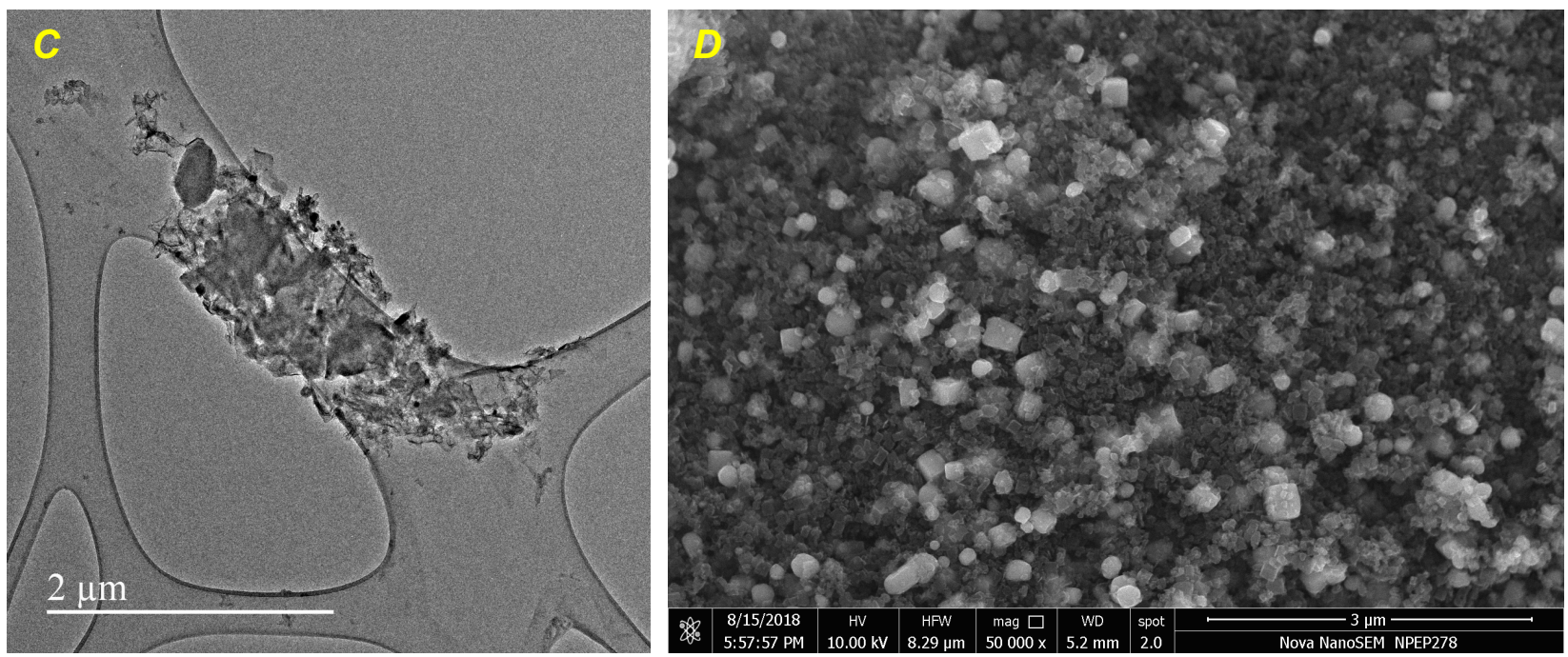

TAL-6-900
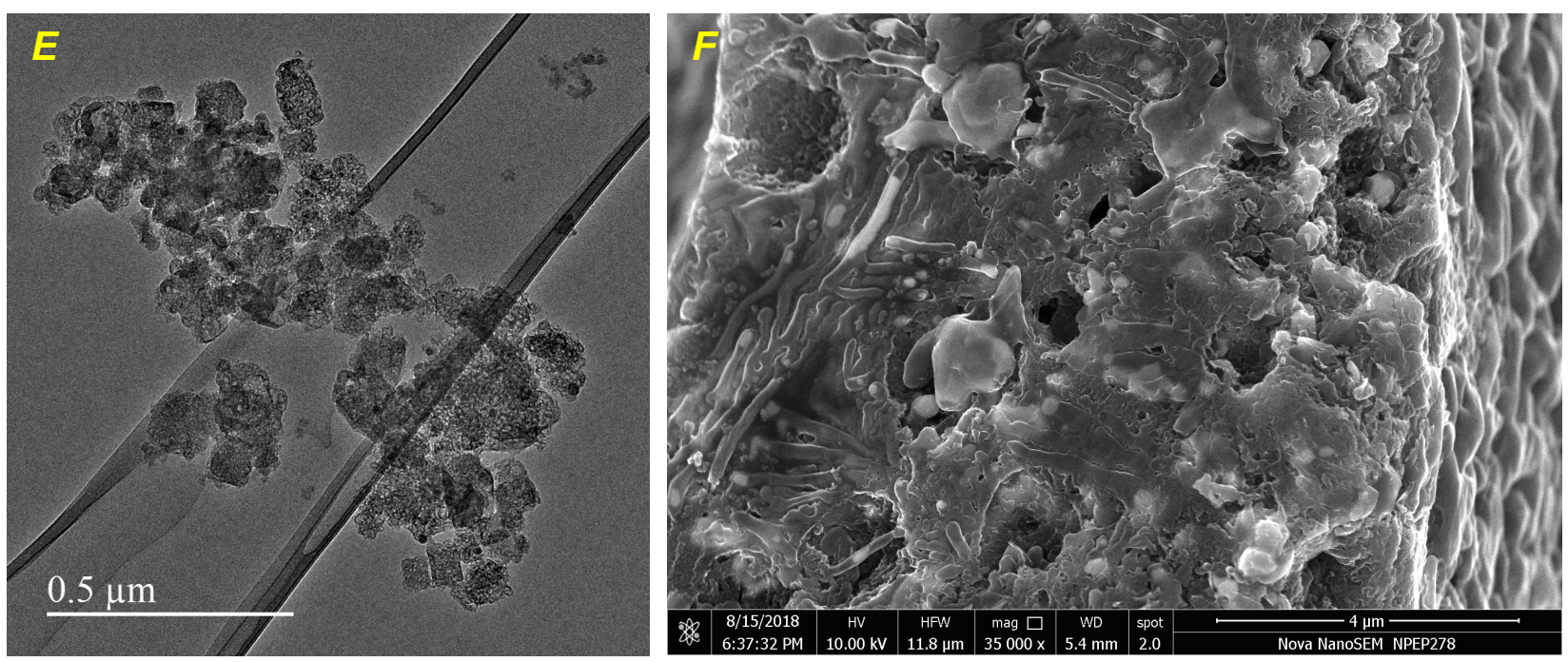

\section{TAL-7-900}

Figure S9. TEM and HRSEM images of TAL-1-900 (a,b), TAL-6-900 (c,d) and TAL-7-900 (e,f) 

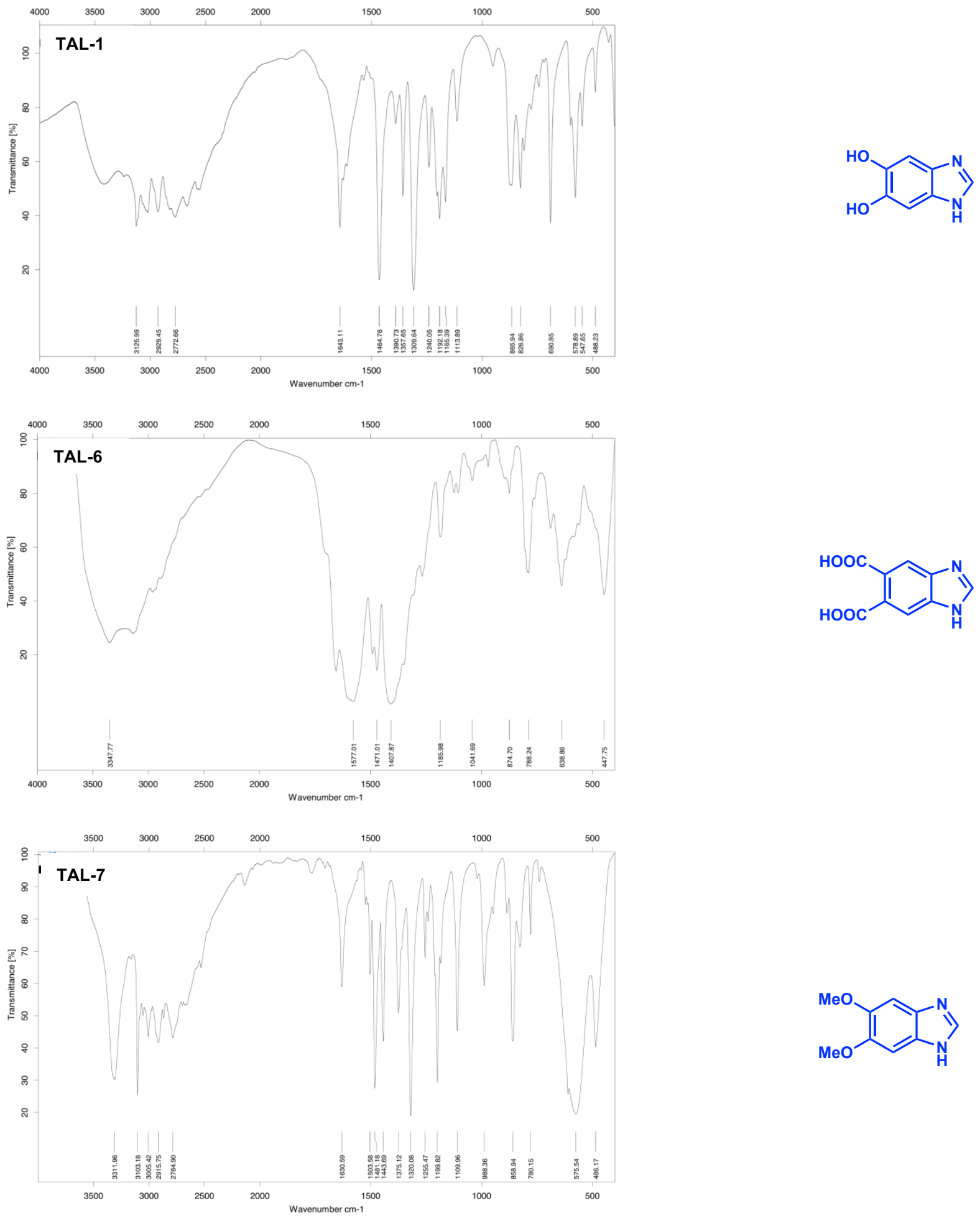

Figure S10. FTIR spectra of TAL-1, TAL-6 and TAL-7 

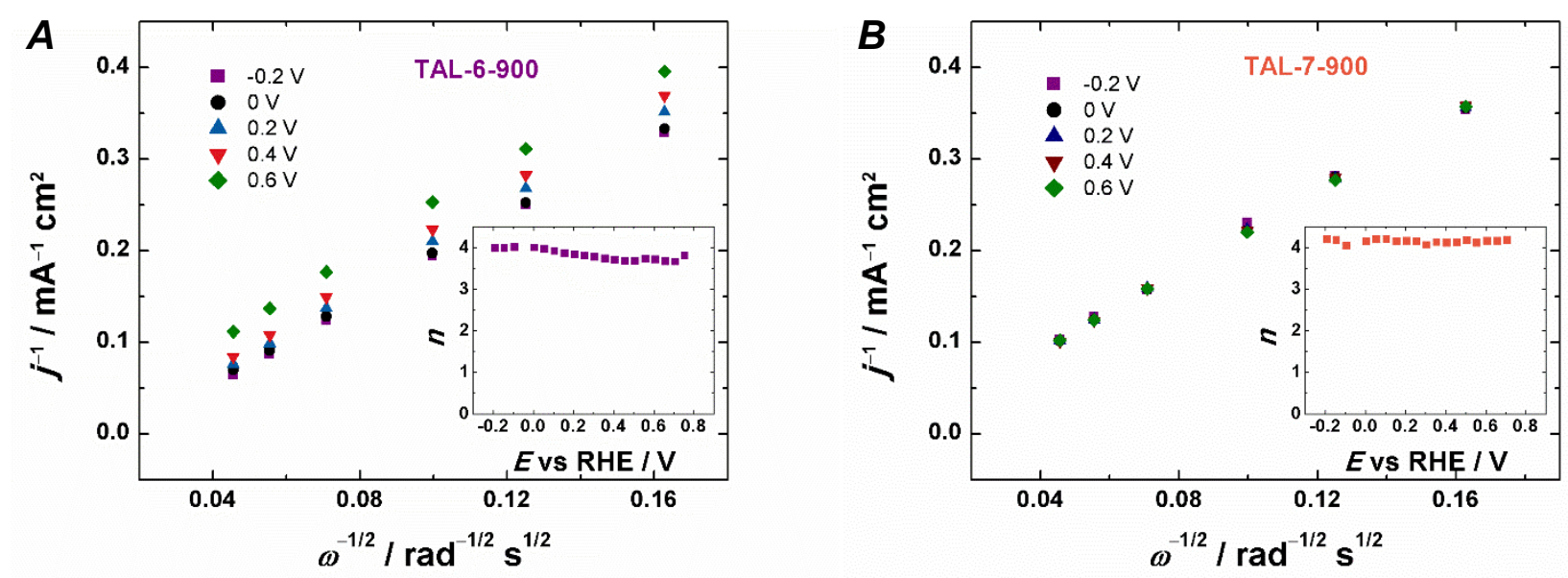

Figure S11. Koutecky-Levich plots for $\mathrm{O}_{2}$ reduction on TAL-6-900 and TAL-7-900 modified GC electrodes; insets: number of electrons transferred per $\mathrm{O}_{2}$ molecule
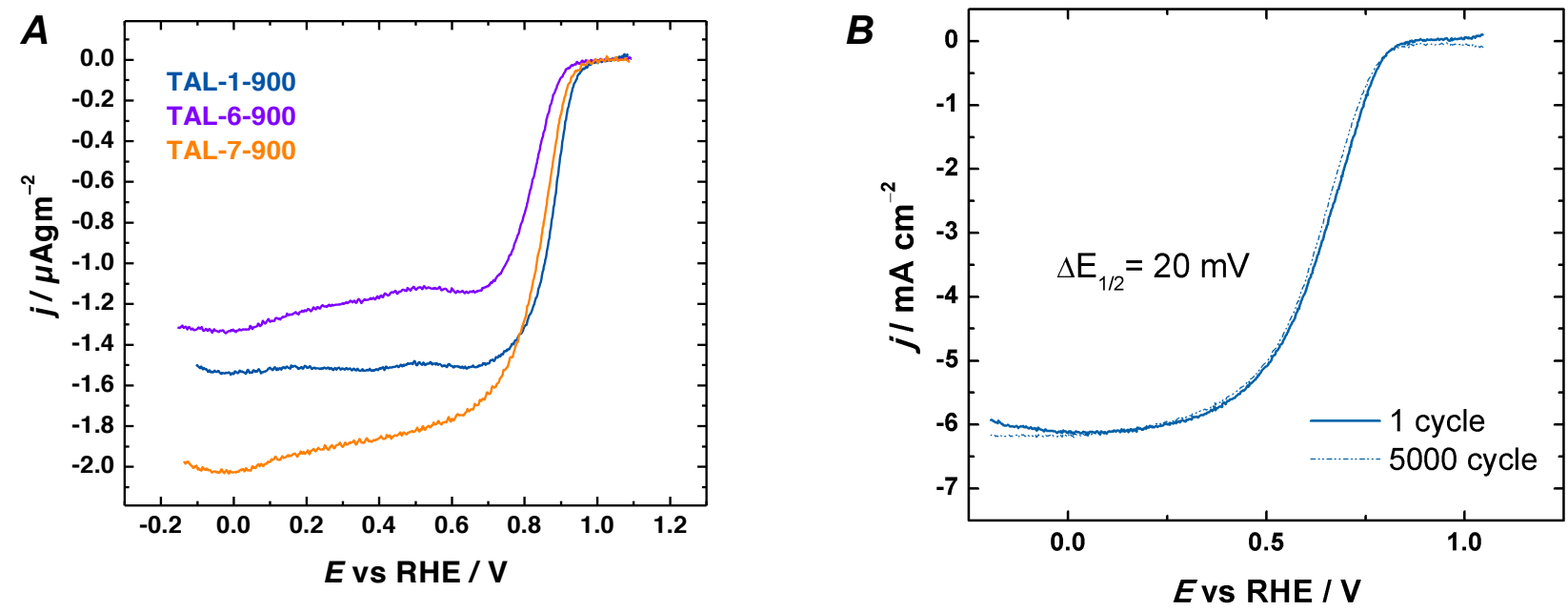

Figure S12. (a) ECSA normalized ORR polarization curves for TAL-X-900 catalyst materials in $\mathrm{O}_{2}$-saturated $0.1 \mathrm{M}$ KOH. (b) Stability of TAL-1-900 catalyst material in $\mathrm{O}_{2}$-saturated $0.5 \mathrm{M} \mathrm{H}_{2} \mathrm{SO}_{4}$ solution. $\omega=1900 \mathrm{rpm}, v=$ $10 \mathrm{mV} \mathrm{s}^{-1}$.

Table S6. ECSA of the catalyst materials and mass-activity determined at $0.85 \mathrm{~V}$ vs. RHE.

\begin{tabular}{|c|c|c|}
\hline catalyst & ECSA $\left(\boldsymbol{m}^{\mathbf{2}} \boldsymbol{g}^{-1}\right)$ & MA $\left(\boldsymbol{m} \boldsymbol{A} \boldsymbol{g}^{-1}\right)$ \\
\hline TAL-1-900 & 504 & 2291 \\
\hline TAL-6-900 & 569 & 1172 \\
\hline TAL-7-900 & 429 & 1852 \\
\hline
\end{tabular}


Table S7. Comparison of OER/ORR bifunctional activity $\left(\Delta E=E_{10}{ }^{\text {OER }}-E_{1 / 2}{ }^{\text {ORR }}\right)$ for different catalysts measured in $0.1 \mathrm{M} \mathrm{KOH}$ [pyrolysis/graphitization was required in all instances]

\begin{tabular}{|c|c|c|c|c|c|}
\hline catalyst & precursors & $\Delta E$ & $\begin{array}{c}\text { OER } \\
E_{10} \\
@ 10 \mathrm{~mA} \mathrm{~cm}^{-2}\end{array}$ & $\begin{array}{c}\text { ORR } \\
E_{1 / 2} \\
@-3 \mathrm{~mA} \mathrm{~cm}^{-2} \\
@ 1600 \mathrm{rpm}\end{array}$ & reference \\
\hline Mn/Fe-HIB-MOF & $\begin{array}{l}\mathrm{Mn}\left(\mathrm{NO}_{3}\right)_{2}+\mathrm{Fe}\left(\mathrm{NO}_{3}\right)_{3}+ \\
\text { hexaminebenzene }\end{array}$ & 0.63 & 1.51 & 0.88 & {$[1]$} \\
\hline NCMT-1000(3D) & facial cotton $+\mathrm{NH}_{3}{ }^{\text {pyrolysis }}$ & 0.63 & 1.52 & 0.89 & {$[2]$} \\
\hline N-GT(FeCoNi)-1000 & $\mathrm{DCDA}+\mathrm{Fe}, \mathrm{Co}, \mathrm{Ni}$ acetates & 0.65 & 1.54 & 0.89 & {$[3]$} \\
\hline CoNi@NCNT/NF & $\mathrm{NF}+$ melamine $+\mathrm{Co}\left(\mathrm{NO}_{3}\right)_{2}$ & 0.67 & 1.54 & 0.87 & {$[4]$} \\
\hline PNGF(op) & $\begin{array}{c}\mathrm{GO}+\mathrm{NH}_{4} \mathrm{H}_{2} \mathrm{PO}_{4}+\left(\mathrm{NH}_{4}\right)_{2} \mathrm{HPO}_{4} \\
+ \text { cyanamide }\end{array}$ & 0.705 & 1.55 & 0.845 & {$[5]$} \\
\hline$T A L-1-900$ & $\begin{array}{c}\text { TAL-1, i.e. } \\
\mathrm{FeCl}_{3}+\text { Ligand } 1\end{array}$ & 0.73 & 1.60 & 0.87 & This work \\
\hline NCNT-700 & $\begin{array}{l}\text { ZIF- } 67+\mathrm{H}_{2}{ }^{\text {pyrolysis }} \text {, i.e } \\
\quad \mathrm{Co}\left(\mathrm{NO}_{3}\right)_{2}+\mathrm{mim}\end{array}$ & 0.73 & 1.60 & 0.87 & {$[6]$} \\
\hline $\mathrm{Co}_{3} \mathrm{O}_{4}-\mathrm{C} / \mathrm{NA}$ & $\mathrm{Co}\left(\mathrm{C}_{12} \mathrm{H}_{6} \mathrm{O}_{4}\right)\left(\mathrm{H}_{2} \mathrm{O}\right)_{4}+\mathrm{Cu}$ foil & 0.74 & 1.52 & 0.78 & {$[7]$} \\
\hline $\mathrm{Co}_{4} \mathrm{~N} / \mathrm{CNW} / \mathrm{CC}$ & $\begin{array}{l}\text { ZIF-67 + polypyrrole nanofibers + } \\
\text { carbon cloths }\end{array}$ & 0.74 & 1.54 & 0.80 & {$[8]$} \\
\hline $\begin{array}{l}\text { NiFe-LDH/ } \\
\text { Fe-N-C (1:3) }\end{array}$ & $\begin{array}{c}\mathrm{Ni}_{0.78} \mathrm{Fe}_{0.22}(\mathrm{OH})_{x} / \mathrm{C} \\
+\mathrm{Fe}-\mathrm{PANI}\end{array}$ & 0.75 & 1.54 & 0.79 & {$[9]$} \\
\hline $\mathrm{S}, \mathrm{N}-\mathrm{Fe} / \mathrm{N} / \mathrm{C}-\mathrm{CNT}$ & $\mathrm{FeCl}_{3}+\mathrm{KSCN}+\mathrm{CNT}+$ bipy & 0.75 & 1.60 & 0.85 & {$[10]$} \\
\hline $\mathrm{Fe} / \mathrm{C} / \mathrm{N}-800$ & $\begin{array}{c}\text { melamine }+\mathrm{HCHO}+\text { Ketjenblack EC- } \\
300 \mathrm{~J}+\mathrm{Fe}\left(\mathrm{NO}_{3}\right)_{3}\end{array}$ & 0.76 & 1.59 & 0.83 & {$[11]$} \\
\hline Fe/N/C-800 & $\begin{array}{c}\mathrm{Fe}(\mathrm{OAc})_{2}+\text { phen }+\mathrm{PTCDA}+\mathrm{BP} 2000 \\
\text { (carbon) }+\mathrm{NH}_{3} \text { pyrolysis }\end{array}$ & 0.76 & 1.60 & 0.84 & {$[12]$} \\
\hline $\mathrm{Co}_{3} \mathrm{O}_{4} / \mathrm{N}-\mathrm{rmGO}$ & $\mathrm{GO}+\mathrm{Co}(\mathrm{OAc})_{2}+\mathrm{NH}_{3}$ & 0.77 & 1.60 & 0.83 & {$[13]$} \\
\hline NCF-900 & ball milling $\mathrm{ZnCl}_{2}$ with cicada sloughs & 0.77 & 1.66 & 0.89 & {$[14]$} \\
\hline $\mathrm{Fe}_{3} \mathrm{C} @ \mathrm{NG} 800-0.2$ & $\begin{array}{c}\text { urea }+ \text { glucose }+\mathrm{Fe}\left(\mathrm{NO}_{3}\right)_{3}+\mathrm{NGCM} \\
\text { (denoted as } \mathrm{NG} 800)\end{array}$ & 0.78 & 1.59 & 0.81 & [15] \\
\hline $\mathrm{Cu} @ N C N T / \mathrm{Co}_{x} \mathrm{O}_{y}$ & $\begin{array}{c}\text { CNTs+CuNP }(\mathrm{Cu} @ \mathrm{CNTs}) \text { cobalt oxide } \\
\left(\mathrm{Co}_{\mathrm{x}} \mathrm{O}_{\mathrm{y}}\right) \mathrm{NP}\end{array}$ & 0.78 & 1.60 & 0.82 & [16] \\
\hline TAL-7-900 & $\begin{array}{c}\text { TAL-7, i.e. } \\
\mathrm{FeCl}_{3}+\text { Ligand } 3\end{array}$ & 0.78 & 1.61 & 0.83 & This work \\
\hline $\mathrm{Ni}-\mathrm{MnO} / \mathrm{rGO}$ & $\mathrm{PVA}+\mathrm{GO}+\mathrm{Mn}(\mathrm{OAc})_{2}+\mathrm{Ni}(\mathrm{OAc})_{2}$ & 0.82 & 1.60 & 0.78 & [17] \\
\hline N-GRW & melamine + cysteine & 0.82 & 1.66 & 0.84 & {$[18]$} \\
\hline$T A L-6-900$ & $\begin{array}{c}\mathrm{TAL}-6, \text { i.e. } \\
\mathrm{FeCl}_{3}+\text { Ligand } 2\end{array}$ & 0.83 & 1.64 & 0.81 & This work \\
\hline $\mathrm{Pt} / \mathrm{C}(20 \mathrm{wt} \%)$ & control & 0.87 & 1.73 & 0.86 & This work \\
\hline $\mathrm{Pt} / \mathrm{C}(20 \mathrm{wt} \%)$ & control & 0.90 & 1.76 & 0.86 & {$[11]$} \\
\hline $\mathrm{IrO}_{2} / \mathrm{C}(20 \mathrm{wt} \%)$ & control & 0.76 & 1.60 & 0.73 & [11] \\
\hline
\end{tabular}

bipy = 2,2'-bipyridine; $\mathrm{DCDA}=$ dicyandiamide; $\mathrm{GO}=$ graphene oxide; $\mathrm{LDH}=$ layered double hydroxide; mim = $\mathrm{N}$-methylimdazole; $\mathrm{NCNT}=\mathrm{N}$ doped carbon nanotubes; NCMT = N-doped carbon microtubes; NF = nickel foam; NG = nanocrystals on graphene; NGCM = N-doped graphene-like carbon materials; phen $=1,10$-phenanthroline; PNGF = P,N-co-doped graphene frameworks; PTCDA = perylenetetracarboxylicdianhydride; PVA = poly(vinyl alcohol) 
PXRD. The powder XRD pattern for TAL-1 were recorded on a Rigaku Ultima IV diffractometer with $\mathrm{Cu} \mathrm{K} \alpha$ radiation $(\lambda=1.5406 \AA, 40 \mathrm{kV}$ at $40 \mathrm{~mA})$ and using the silicon strip detector $\mathrm{D} / \mathrm{teX}$ Ultra with the scan range of $2 \theta=10.0-60.0^{\circ}$, scan step $0.02^{\circ}$, scan speed $5 \mathrm{deg} / \mathrm{min}$. The powder XRD patterns for the rest incl. additional run for TAL-1 were recorded on a Bruker D8 Advanced diffractometer using Ni filtered $\mathrm{Cu}$ Ka radiation and LynxEye line detector. Scanning steps were $0.013^{\circ} 2 \theta$ from $5^{\circ}$ to $90^{\circ} 2 \theta$ and total counting time was $173 \mathrm{~s}$ per step. The

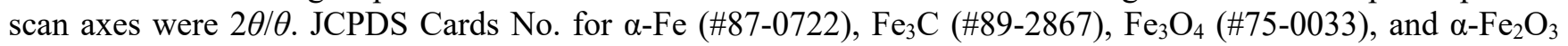
(\#33-0664).

SEM. Surface morphology was studied by scanning electron microscopy (SEM) using Zeiss Ultra-55. The solid was deposited onto the carbon tape (TAL-1, TAL-6 and TAL-7 samples were covered with a thin gold layer to improve conductivity).

XPS. The surface elemental composition was investigated by X-ray photoelectron spectroscopy (XPS) using the Scienta SES-100 spectrometer. For preparing the samples, the catalytic materials were dispersed in isopropanol at a concentration of $2 \mathrm{mg} \mathrm{mL}^{-1}$ and deposited onto GC plates $(1.1 \times 1.1 \mathrm{~cm})$. The samples were tested with a nonmonochromatic twin anode X-ray tube (XR3E2), where the characteristic energies were $1253.6 \mathrm{eV}\left(\mathrm{Mg} \mathrm{Ka}_{1,2}\right.$, FWHM $0.68 \mathrm{eV})$ and $1486.6 \mathrm{eV}\left(\mathrm{Al} \mathrm{Ka}_{1,2}\right.$, FWHM $\left.0.83 \mathrm{eV}\right)$. The pressure in the analysis chamber was below 109 Torr and the source power was $300 \mathrm{~W}$. Survey spectra were obtained using the following parameters: energy range 800 to $0 \mathrm{eV}$, pass energy $200 \mathrm{eV}$, step size $0.5 \mathrm{eV}$. High resolution XPS scans were performed using pass energy $200 \mathrm{eV}$ and step size $0.1 \mathrm{eV}$. An Ag wire attached to the sample holders was used for energy reference (Ag $3_{\mathrm{d} 5 / 2}$ at $367.8 \mathrm{eV}$ ), no charging effects were observed. Peak fitting was done using CasaXPS (version 2.3.16) software.

HRTEM. Scanning transmission electron microscopy was done using FEI Titan 200 with $200 \mathrm{keV}$ electron beam.

BET. Low-temperature nitrogen adsorption was done at the boiling temperature of nitrogen $(77 \mathrm{~K})$ by using the NOVAtouch LX ${ }^{2}$ (Quantachrome Instruments). Specific surface $\left(S_{\mathrm{BET}}\right)$ of carbon samples was calculated from $\mathrm{N}_{2}$ adsorption corresponding to the BET theory in the $P / P_{0}$ interval of $0.02-0.2$, the total pore volume $\left(V_{t o t}\right)$, calculated at $P / P_{0}$ of 0.97 . The calculations of pore size distribution and specific surface $\left(S_{\mathrm{DFT}}\right)$ from $\mathrm{N} 2$ isotherms were done by using a quenched solid density functional theory (QSDFT) equilibria model for slit type pores.

Raman Spectroscopy. Micro-Raman spectra were recorded by using a Horiba's LabRam HR800 spectrometer with a $532 \mathrm{~nm}$ laser line.

IR. Measured on Bruker Tensor 27 FT-IR using KBr pellets.

MP-AES. Analytical samples were digested in Anton Paar Multiwave PRO microwave digestion system using NXF100 vessels (PTFE/TFM liner) in 8NXF100 rotor. TAL-X-900 samples $(10 \mathrm{mg})$ were dissolved in $69 \% \mathrm{HNO}_{3}$ $(4 \mathrm{~mL})$ and $\mathrm{H}_{2} \mathrm{O}_{2}(2 \mathrm{~mL})$, then $48 \% \mathrm{HF}(0.1 \mathrm{~mL})$ was added, the vessels were capped and digested in the microwave unit. After digestion, the samples were diluted using $2 \% \mathrm{HNO}_{3}$ to a final dilution factor of 61,000 and analyzed using Agilent $4210 \mathrm{MP}-\mathrm{AES}$. Fe and Lu (an internal standard added online via a T-shaped micro-mixer) were measured at 371.993 and $547.669 \mathrm{~nm}$, respectively.

Elemental analyses were performed on PerkinElmer ${ }^{\circledR} 2400$ Series II CHNS/O Elemental Analyzer.

Electroanalytical studies. All electrochemical measurements, including ORR and OER tests were performed in a three-electrode glass cell, using a rotating disk electrode (RDE) setup and an Autolab potentiostat/galvanostat PGSTAT30 (Eco Chemie B.V.). A glassy carbon (GC) rod served as counter electrode. Potentials were measured against a reversible hydrogen electrode (RHE) connected to the cell through a Luggin capillary. GC disks (geometric area of $0.126 \mathrm{~cm}^{2}$ ) polished to a mirror finish with 1 and $0.3 \mu \mathrm{m}$ alumina slurries (Buehler) pressed into a Teflon holder served as working electrodes. 
Prior to modification, the GC electrode was sonicated in both isopropanol and Milli-Q water for 5 min to remove polishing residues. The catalyst suspension was homogenized by sonication for $30 \mathrm{~min}$ and catalyst suspension was spin-coated onto the GC electrode and allowed to dry in air, yielding the catalyst loading of $800 \mu \mathrm{g} \mathrm{cm}^{-2}$.

The electrolyte solution was prepared using Milli-Q water, $\mathrm{KOH}$ pellets (p.a. quality, Merck); saturated with pure $\mathrm{O}_{2}(99.999 \%$, AGA) and deaerated with Ar gas (99.999\%, AGA). Comparison experiments were performed with $20 \mathrm{wt} \% \mathrm{Pt} / \mathrm{C}\left(\mathrm{E}-\mathrm{TEK}\right.$; loading of $20 \mu \mathrm{g}_{\mathrm{Pt}} \mathrm{cm}^{-2}$ ) and $99.9 \% \mathrm{RuO}_{2}$ (Alfa Aesar; loading of $200 \mu \mathrm{g} \mathrm{cm}^{-2}$ ).

The RDE technique was used to explore the electrocatalytic activity of the catalysts towards the ORR. Cyclic voltammograms were recorded at a potential sweep rate $(v)$ of $50 \mathrm{mV} \mathrm{s}^{-1}$ in Ar-saturated solution in the potential range of $-0.1 \div 1.4 \mathrm{~V}$. The RDE polarization curves were measured in $\mathrm{O}_{2}$-saturated $0.1 \mathrm{M} \mathrm{KOH}$ solution at a scan rate of $10 \mathrm{mV} \mathrm{s}^{-1}$ in the potential range of $-0.1 \div 1.1 \mathrm{~V}$ at different electrode rotation rates $(\omega)$ : $360-4600 \mathrm{rpm}$. Electrode rotation rate was controlled using a CTV101 speed control unit connected to an EDI101 rotator (Radiometer). Background currents (not shown) were measured in Ar-saturated solution at a scan rate $10 \mathrm{mV} \mathrm{s}^{-1}$ in the potential range of $-0.1 \div 1.1 \mathrm{~V}$. The background correction was made by subtracting background currents from the RDE data. The data was normalized to the geometric area of the GC electrode. The ORR and OER data were automatically corrected for iR drop using Nova software. Electrochemical Impedance Spectroscopy (EIS) was used to determine the $R$ value, which was 46,53 and $57 \Omega$ for TAL-1-900, TAL-6-900 and TAL-7-900 modified GC electrodes in $0.1 \mathrm{M} \mathrm{KOH}$ solution, respectively.

Koutecky-Levich $(\mathrm{K}-\mathrm{L})$ plots at various electrode potentials were constructed from the RDE data. The number of electrons transferred per $\mathrm{O}_{2}$ molecule $(n)$ was calculated from the $\mathrm{RDE}$ data using the $\mathrm{K}-\mathrm{L}$ equation:

$$
\frac{1}{j}=\frac{1}{j_{k}}+\frac{1}{j_{d}}=-\frac{1}{n F k C_{o_{2}}^{b}}-\frac{1}{0.62 n F D_{O_{2}}^{2 / 3} v^{-1 / 6} C_{o_{2}}^{b} \omega^{1 / 2}}
$$

where $j$ denotes the measured current density at a specific potential, while $j_{\mathrm{k}}$ and $j_{\mathrm{d}}$ are the kinetic and diffusionlimited current densities, respectively. $F$ denotes the Faraday constant $\left(96,485 \mathrm{C} \mathrm{mol}^{-1}\right), k$ is the rate constant for electrochemical reduction of oxygen, $\boldsymbol{C}_{\boldsymbol{O}_{2}}^{\boldsymbol{b}}$ denotes the concentration of $\mathrm{O}_{2}\left(1.2 \times 10^{-6} \mathrm{~mol} \mathrm{~cm}^{-3}\right.$ in $\left.0.1 \mathrm{M} \mathrm{KOH}\right)$ while $\boldsymbol{D}_{\boldsymbol{O}_{2}}$ represents the diffusion coefficient of $\mathrm{O}_{2}\left(1.9 \times 10^{-5} \mathrm{~cm}^{2} \mathrm{~s}^{-1}\right.$ in $\left.0.1 \mathrm{M} \mathrm{KOH}\right), v$ is the kinematic viscosity of the solution $\left(0.01 \mathrm{~cm}^{2} \mathrm{~s}^{-1}\right)$ and $\omega$ is the rotation rate of the electrode $\left(\mathrm{rad} \mathrm{s}^{-1}\right)$.

Accelerated durability tests were also performed by cycling electrodes 5000 times in the potential range between 0.6 and $1 \mathrm{~V} v s$. RHE (ORR) and between 1.0 and $1.8 \mathrm{~V} v s$. RHE (OER) in $0.1 \mathrm{M} \mathrm{KOH}$, using a scan rate of 100 $\mathrm{mV} \mathrm{s}^{-1}$. RDE polarization curves for ORR and OER were recorded before and after 5000 cycles and compared. The spent catalysts were characterized by PXRD and HRTEM. The chronoamperometry measurements were conducted at the potential of $1.6 \mathrm{~V} v s$. RHE and lasted for 10000 seconds in total. All experiments were carried out at room temperature $\left(23 \pm 1^{\circ} \mathrm{C}\right)$.

To calculate specific activity (SA) values, the real surface area $\left(A_{\mathrm{r}}\right)$ of catalyst material has to be determined (SA $=I_{\mathrm{k}} / A_{\mathrm{r}}$ where $\mathrm{I}_{\mathrm{k}}$ denotes the measured kinetic current at a specific potential), which in the case of $\mathrm{Fe} / \mathrm{N} / \mathrm{C}$ type materials can sometimes be hard to predict. Generally, it is assumed that catalytic sites are of equal activity, however, in the TAL-1/6/7-900 catalyst series, we assume that different starting TAL precursors lead to different carbon networks. Due to the variety of active sites on the catalyst surface we doubt that a simple calculation of the SA values by normalizing the kinetic current to the real surface area of the catalyst allows one to determine the intrinsic ORR activity of the electrocatalysts studied in the present work.

We calculated the ECSA values using ratio of pseudo-capacitance connected with the electrolyte accessible area of the catalyst material and double layer capacitance of the glassy carbon electrode surface. This approach showed the capacity to produce results of medium to high precision. The results are in a reasonable agreement with the values obtained from BET measurements of the specific surface area.

The mass activity (MA) values were calculated at $0.85 \mathrm{~V}$ vs. RHE using the following equation: $\mathrm{MA}=\mathrm{I}_{\mathrm{k}} / \mathrm{m}_{\text {catalyst}}$, where $m_{\text {catalyst }}$ represents the nominal catalyst mass on the electrode surface. ECSA was estimated according to electrochemical double-layer capacitance $\left(C_{\mathrm{dl}}\right)$ based on the positive proportional relationship between ECSA and 
$C_{\mathrm{dl}}$. ECSA was calculated using the ratio of pseudo-capacitance connected with the electrolyte accessible area of the catalyst material and double layer capacitance of glassy carbon electrode surface.

\section{$3 \quad$ Synthetic Procedures}

\section{General}

All chemicals were used as supplied. Thin-layer chromatography was performed on Merck TLC Silica gel $60 \mathrm{~F}_{254}$ and visualized by UV $(254 \mathrm{~nm}), \mathrm{KMnO}_{4}$ and/or phosphomolybdic acid. ${ }^{1} \mathrm{H}$ and ${ }^{13} \mathrm{C}$ NMR spectra were recorded on Bruker Avance 400 spectrometer. Residual solvent peaks were used as internal standards [19]. Chemical shifts are quoted in ppm using the following abbreviations: $s$ singlet; $b r$ broad; or a combination thereof.

\section{Preparation of Organic Linkers}

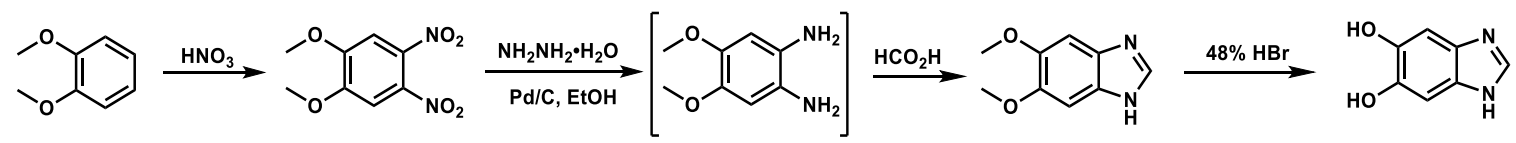

\section{1,2-Dimethoxy-4,5-dinitrobenzene [20]}

1,2-Dimethoxybenzene (11.08 g, $80.19 \mathrm{mmol}, 1.0$ equiv) was added dropwise into conc. $\mathrm{HNO}_{3}(100 \mathrm{~mL}, 65 \%)$ at $0{ }^{\circ} \mathrm{C}$, after addition, the mixture was left to stir at $80^{\circ} \mathrm{C}$. After $2 \mathrm{~h}$, the mixture was cooled down to $0{ }^{\circ} \mathrm{C}$, and the resulting precipitate was washed with distilled water until neutral to give the desired compound as a yellow needle crystal $(15.39 \mathrm{~g}, 67.45 \mathrm{mmol}, 84 \%)$.

${ }^{1} \mathrm{H}$ NMR $\left(400 \mathrm{MHz}, \mathrm{CDCl}_{3}\right) \delta 7.33(\mathrm{~s}, 2 \mathrm{H}), 4.01(\mathrm{~s}, 6 \mathrm{H})$.

${ }^{13} \mathrm{C}$ NMR $\left(100 \mathrm{MHz}, \mathrm{CDCl}_{3}\right) \delta 152.0,136.8,107.1,57.2$.

\section{5,6-Dimethoxy-1H-benzo[d] imidazole [20]}

Hydrazine monohydrate $(22.6 \mathrm{~mL}, 464.7 \mathrm{mmol}, 10.8$ equiv) was added dropwise to a solution of 1,2-dimethoxy4,5-dinitrobenzene $\left(9.85 \mathrm{~g}, 43.2 \mathrm{mmol}, 1.0\right.$ equiv) and $\mathrm{Pd} / \mathrm{C}(10 \%, 0.985 \mathrm{~g})$ in anhydrous EtOH $(60 \mathrm{~mL})$ at $0{ }^{\circ} \mathrm{C}$, after addition, the mixture was left to stir at $80{ }^{\circ} \mathrm{C}$. After $30 \mathrm{~min}$, the mixture was filtered through silica gel (CAUTION! Pd/C on silica gel may catch fire!), concentrated under reduced pressure, to which formic acid (98\%, $100 \mathrm{~mL}$ ) was added, and the mixture was left to stir at $100{ }^{\circ} \mathrm{C}$. After $16 \mathrm{~h}$, the mixture was concentrated under reduced pressure, water $(50 \mathrm{~mL})$ added, and the solution was basified with solid $\mathrm{K}_{2} \mathrm{CO}_{3}$. The precipitate was collected, washed with water and dried to give the desired compound as a colorless solid (7.00 g, $39.3 \mathrm{mmol}, 91 \%)$. ${ }^{1} \mathrm{H}$ NMR (400 MHz, DMSO- $\left.d_{6}\right) \delta 8.03(\mathrm{~s}, 1 \mathrm{H}), 7.14(\mathrm{~s}, 2 \mathrm{H}), 3.82(\mathrm{~s}, 6 \mathrm{H})$.

${ }^{13} \mathrm{C}$ NMR (100 MHz, DMSO- $\left.d_{6}\right) \delta 147.2,141.1,132.5,99.2,56.8$.

\section{$1 H$-Benzo[d]imidazole-5,6-diol [20]}

5,6-Dimethoxy- $1 H$-benzo[ $d$ ]imidazole $(7.79 \mathrm{~g}, 43.7 \mathrm{mmol}, 1.0$ equiv) was added into $\mathrm{HBr}(48 \%, 50 \mathrm{~mL})$, and the mixture was left to stir at $120^{\circ} \mathrm{C}$. After $4 \mathrm{~h}$, the mixture was cooled down to $0{ }^{\circ} \mathrm{C}$, and the precipitate was collected, washed with petroleum ether to give the desired compound as a colorless solid (4.59 g, $30.6 \mathrm{mmol}, 70 \%)$.

${ }^{1} \mathrm{H}$ NMR (400 MHz, DMSO) $\delta 9.75$ (s, 2H), 9.25 (s, 1H), 7.12 (s, 2H).

${ }^{13} \mathrm{C}$ NMR (100 MHz, DMSO) $\delta 146.4,136.9,123.7,98.4$.

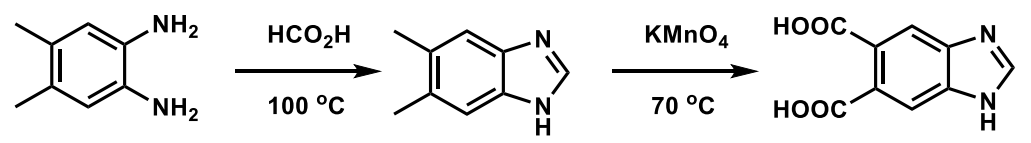

\section{5,6-Dimethyl-1H-benzo[d]imidazole [21]}

A solution of 4,5-dimethylbenzene-1,2-diamine (2.024 g, $14.860 \mathrm{mmol}, 1.0$ equiv) in formic acid (10 $\mathrm{mL})$ was left to stir at $100{ }^{\circ} \mathrm{C}$. After $4 \mathrm{~h}$, the mixture was concentrated under reduced pressure, water added, the solution was basified with solid $\mathrm{K}_{2} \mathrm{CO}_{3}$, and the precipitate was collected, washed with water and dried to give the desired product as a colorless solid $(1.813 \mathrm{~g}, 12.402 \mathrm{mmol}, 83 \%)$.

${ }^{1} \mathrm{H}$ NMR (400 MHz, DMSO- $d_{6}$ ) $\delta 12.18$ (br s, 1H), 8.05 (s, 1H), $7.34(\mathrm{~s}, 2 \mathrm{H}), 2.30(\mathrm{~s}, 6 \mathrm{H})$. 
${ }^{13} \mathrm{C}$ NMR $\left(100 \mathrm{MHz}\right.$, DMSO- $\left.d_{6}\right) \delta 141.0,130.1,20.0$, two carbons not observed.

\section{$1 H$-Benzo[d]imidazole-5,6-dicarboxylic acid [22]}

A solution of $\mathrm{KMnO}_{4}(19.594 \mathrm{~g}, 123.990 \mathrm{mmol}, 10$ equiv) was added dropwise into a solution of 5,6-dimethyl$1 H$-benzo[ $d]$ imidazole $(1.813 \mathrm{~g}, 12.3990 \mathrm{mmol}, 1.0$ equiv) in water $/ t$ - BuOH $(16 \mathrm{~mL} / 16 \mathrm{~mL})$, the mixture was left to stir gradually heating up to $70{ }^{\circ} \mathrm{C}$. After addition, heating was turned off, the mixture was left to stir at RT for 15 min, after which $\mathrm{Na}_{2} \mathrm{SO}_{3}(4.765 \mathrm{~g}, 37.805 \mathrm{mmol}, 3.0$ equiv) was added, the mixture was then left to stir at 80 ${ }^{\circ} \mathrm{C}$. After $30 \mathrm{~min}$, the mixture was filtered through Celite, washed with boiling water, filtrate was concentrated under reduced pressure to approximately $50 \mathrm{~mL}$, diluted with water, cooled down to $0{ }^{\circ} \mathrm{C}$, acetic acid/water $(18$ $\mathrm{mL} / 9 \mathrm{~mL}$ ) added, precipitate was collected, dried to give the desired product as a colorless solid $(711.2 \mathrm{mg}, 3.4497$ mmol, 28\%).

${ }^{1} \mathrm{H}$ NMR $\left(400 \mathrm{MHz}, \mathrm{DMSO}-d_{6}\right) \delta 8.45(\mathrm{~s}, 1 \mathrm{H}), 7.91(\mathrm{~s}, 2 \mathrm{H})$.

${ }^{13} \mathrm{C}$ NMR $\left(100 \mathrm{MHz}, \mathrm{DMSO}-d_{6}\right) \delta 169.1,145.5,127.5,116.3$, one carbon was not observed.

\section{Preparation of TAL-1}

$\mathrm{FeCl}_{3} 6 \mathrm{H}_{2} \mathrm{O}(2.97 \mathrm{~g}, 10.99 \mathrm{mmol}, 1.0$ equiv) and $1 H$-benzo[d]imidazole-5,6-diol (3.30 g, $21.98 \mathrm{mmol}, 2.0$ equiv) was dissolved in a mixture of DMF $(15 \mathrm{~mL})$ and distilled water $(15 \mathrm{~mL})$, and the mixture was left to react at 100 ${ }^{\circ} \mathrm{C}$. After $72 \mathrm{~h}$, the mixture was cooled down to RT, centrifuged, washed with DMF $(3 \times 10 \mathrm{~mL})$, and dried to give the desired material as a black solid $(2.32 \mathrm{~g})$.

\section{Preparation of TAL-6}

A solution of $\mathrm{FeCl}_{3} \cdot 6 \mathrm{H}_{2} \mathrm{O}$ (440 mg, $1.629 \mathrm{mmol}, 1.0$ equiv) and $1 H$-benzo[d]imidazole-5,6-dicarboxylic acid (671 $\mathrm{mg}, 3.255 \mathrm{mmol}, 2.0$ equiv) in $\mathrm{DMF} /$ water $(3 \mathrm{~mL} / 3 \mathrm{~mL})$ was left to stir at $100{ }^{\circ} \mathrm{C}$. After $72 \mathrm{~h}$, the mixture was cooled down to RT, centrifuged, the precipitate was washed with DMF $(3 \times 10 \mathrm{~mL})$, and dried to give the desired material as a yellow solid (593 $\mathrm{mg})$.

\section{Preparation of TAL-7}

A solution of $\mathrm{FeCl}_{3} \cdot 6 \mathrm{H}_{2} \mathrm{O}$ (758 mg, $2.804 \mathrm{mmol}, 1.0$ equiv) and 5,6-dimethoxy- $1 \mathrm{H}$-benzo[ $\left.d\right]$ imidazole $(1.00 \mathrm{~g}$, $5.610 \mathrm{mmol}, 2.0$ equiv) in DMF/water $(3 \mathrm{~mL} / 3 \mathrm{~mL})$ was left to stir at $100{ }^{\circ} \mathrm{C}$. After $72 \mathrm{~h}$, the mixture was cooled down to RT, centrifuged, the precipitate was washed with DMF $(3 \times 10 \mathrm{~mL})$, and dried to give the desired material as a red solid (599 $\mathrm{mg})$.

\section{Carbonization}

Carbonization was undertaken at $900{ }^{\circ} \mathrm{C}\left(\mathrm{N}_{2}\right.$, rapid heat, $2 \mathrm{~h}$, slow cooling). Carbonized materials were suspended in a 1:1 mixture of $0.5 \mathrm{M} \mathrm{H}_{2} \mathrm{SO}_{4}$ and $0.5 \mathrm{M} \mathrm{HNO}_{3}$, stirred for $8 \mathrm{~h}$ at $50{ }^{\circ} \mathrm{C}$, filtered, and re-carbonized under $\mathrm{N}_{2}$ at $900{ }^{\circ} \mathrm{C}$ for $2 \mathrm{~h}$ to give the acid leached materials TAL-1-900, TAL-6-900 and TAL-7-900. 
1. Shinde, S. S.; Lee, C. H.; Jung, J. Y.; Wagh, N. K.; Kim, S. H.; Kim, D. H.; Lin, C.; Lee, S. U.; Lee, J. H. Unveiling dual-linkage 3D hexaiminobenzene metal-organic frameworks towards long-lasting advanced reversible Zn-air batteries. Energy Environ. Sci. 2019, 12, 727-738. doi:10.1039/c8ee02679c

2. $\quad$ Li, J. C.; Hou, P. X.; Zhao, S. Y.; Liu, C.; Tang, D. M.; Cheng, M.; Zhang, F.; Cheng, H. M. A 3D bifunctional porous $\mathrm{N}$-doped carbon microtube sponge electrocatalyst for oxygen reduction and oxygen evolution reactions. Energy Environ. Sci. 2016, 9, 3079-3084. doi:10.1039/c6ee02169g

3. Gupta, S.; Qiao, L.; Zhao, S.; Xu, H.; Lin, Y.; Devaguptapu, S. V.; Wang, X.; Swihart, M. T.; Wu, G. Highly active and stable graphene tubes decorated with FeCoNi alloy nanoparticles via a template-free graphitization for bifunctional oxygen reduction and evolution. Adv. Energy Mater. 2016, 6, 1601198. doi:10.1002/aenm.201601198

4. $\quad$ Niu, W.; Pakhira, S.; Marcus, K.; Li, Z.; Mendoza-Cortes, J. L.; Yang, Y. Apically dominant mechanism for improving catalytic activities of $\mathrm{N}$-doped carbon nanotube arrays in rechargeable Zinc-air battery. $A d v$. Energy Mater. 2018, 8, 1800480. doi:10.1002/aenm.201800480

5. $\quad$ Chai, G. L.; Qiu, K.; Qiao, M.; Titirici, M. M.; Shang, C.; Guo, Z. Active sites engineering leads to exceptional ORR and OER bifunctionality in P, N Co-doped graphene frameworks. Energy Environ. Sci. 2017, 10, 1186-1195. doi:10.1039/c6ee03446b

6. Xia, B.Y.; Yan, Y.; Li, N.; Wu, H. B.; Lou, X. W. D.; Wang, X. A metal-organic framework-derived bifunctional oxygen electrocatalyst. Nat. Energy. 2016, 1, 15006. doi:10.1038/nenergy20156

7. Ma, T.Y.; Dai, S.; Jaroniec, M.; Qiao, S. Z. Metal-organic framework derived hybrid $\mathrm{Co}_{3} \mathrm{O}_{4}$-carbon porous nanowire arrays as reversible oxygen evolution electrodes. J. Am. Chem. Soc. 2014, 136, 13295-13931. doi:10.1021/ja5082553

8. Meng, F.; Zhong, H.; Bao, D.; Yan, J.; Zhang, X. In situ coupling of strung $\mathrm{Co}_{4} \mathrm{~N}$ and intertwined N-C fibers toward free-standing bifunctional cathode for robust, efficient, and flexible $\mathrm{Zn}$-air batteries. $J$. Am. Chem. Soc. 2016, 138, 10226-10231. doi:10.1021/jacs.6b05046

9. Dresp, S.; Luo, F.; Schmack, R.; Kühl, S.; Gliech, M.; Strasser, P. An efficient bifunctional two-component catalyst for oxygen reduction and oxygen evolution in reversible fuel cells, electrolyzers and rechargeable air electrodes. Energy Environ. Sci. 2016, 9, 2020-2024. doi:10.1039/c6ee01046f

10. Chen, P.; Zhou, T.; Xing, L.; Xu, K.; Tong, Y.; Xie, H.; Zhang, L.; Yan, W.; Chu, W.; Wu, C.; Xie, Y. Atomically dispersed iron-nitrogen species as electrocatalysts for bifunctional oxygen evolution and reduction reactions. Angew. Chem. Int. Ed. 2017, 56, 610-614. doi:10.1002/anie.201610119

11. Zhao, Y.; Kamiya, K.; Hashimoto, K.; Nakanishi, S. Efficient bifunctional Fe/C/N electrocatalysts for oxygen reduction and evolution reaction. J. Phys. Chem. C. 2015, 119, 2583-2588. doi:10.1021/jp511515q

12. Lefèvre, M.; Proietti, E.; Jaouen, F.; Dodelet, J. P. Iron-based catalysts with improved oxygen reduction activity in polymer electrolyte fuel cells. Science. 2009, 324, 71-74. doi:10.1126/science.1170051

13. Liang, Y.; Li, Y.; Wang, H.; Zhou, J.; Wang, J.; Regier, T.; Dai, $\mathrm{H}_{\text {. }} \mathrm{Co}_{3} \mathrm{O}_{4}$ nanocrystals on graphene as a synergistic catalyst for oxygen reduction reaction. Nat. Mater. 2011, 10, 780-786. doi:10.1038/nmat3087

14. Yang, X.; Li, K.; Cheng, D.; Pang, W.L.; Lv, J.; Chen, X.; Zang, H. Y.; Wu, X. L.; Tan, H. Q.; Wang, Y. H.; Li, Y. G. Nitrogen-doped porous carbon: Highly efficient trifunctional electrocatalyst for oxygen reversible catalysis and nitrogen reduction reaction. J. Mater. Chem. A. 2018, 6, 7762-7769. doi:10.1039/c8ta01078a

15. Jiang, H.; Yao, Y.; Zhu, Y.; Liu, Y.; Su, Y.; Yang, X.; Li, C. Iron carbide nanoparticles encapsulated in mesoporous $\mathrm{Fe}-\mathrm{N}$-doped graphene-like carbon hybrids as efficient bifunctional oxygen electrocatalysts. ACS Appl. Mater. Inter. 2015, 7, 21511-21520. doi:10.1021/acsami.5b06708 
16. Zhao, X.; Li, F.; Wang, R.; Seo, J.M.; Choi, H.J.; Jung, S. M.; Mahmood, J.; Jeon, I. Y.; Baek, J. B. Controlled fabrication of hierarchically structured nitrogen-doped carbon nanotubes as a highly active bifunctional oxygen electrocatalyst. Adv. Funct. Mater. 2017, 27, 1605717. doi:10.1002/adfm.201605717

17. Fu, G.; Yan, X.; Chen, Y.; Xu, L.; Sun, D.; Lee, J. M.; Tang, Y. Boosting bifunctional oxygen electrocatalysis with 3D graphene aerogel-supported Ni/MnO particles. Adv. Mater. 2018, 30, 1704609. doi:10.1002/adma.201704609

18. Yang, H. B.; Miao, J.; Hung, S. F.; Chen, J.; Tao, H. B.; Wang, X.; Zhang, L.; Chen, R.; Gao, J.; Chen, H.M.; Dai, L. Identification of catalytic sites for oxygen reduction and oxygen evolution in N-doped graphene materials: Development of highly efficient metal-free bifunctional electrocatalyst. Sci. Adv. 2016, 2, e1501122. doi:10.1126/sciadv.1501122

19. Gottlieb, H. E.; Kotlyar, V.; Nudelman, A. NMR chemical shifts of common laboratory solvents as trace impurities. J. Org. Chem. 1997, 62, 7512-7515. doi:10.1021/jo971176v

20. Fan, K. W.; Peterson, M. B.; Ellersdorfer, P.; Granville, A. M. Expanding the aqueous-based redoxfacilitated self-polymerization chemistry of catecholamines to 5,6-dihydroxy- $1 H$-benzimidazole and its 2substituted derivatives. $R S C A d v$. 2016, 6, 25203-25214. doi:10.1039/c5ra25590b

21. Karuvalam, R. P.; Siji, M.; Divia, N.; Haridas, K. R. Tetra-butyl ammonium chloride catalyzed synthesis of substituted benzimidazoles under microwave conditions. J. Kor. Chem. Soc. 2010, 54, 589-593. doi:10.5012/jkcs.2010.54.5.589

22. Leonard, N. J.; Kazmierczak, F. A convenient synthesis of linear benzopurines through a common intermediate. J. Org. Chem. 1987, 52, 2933-2935. doi:10.1021/jo00389a055 


\section{$5 \quad$ NMR Spectra}

\section{1,2-Dimethoxy-4,5-dinitrobenzene}
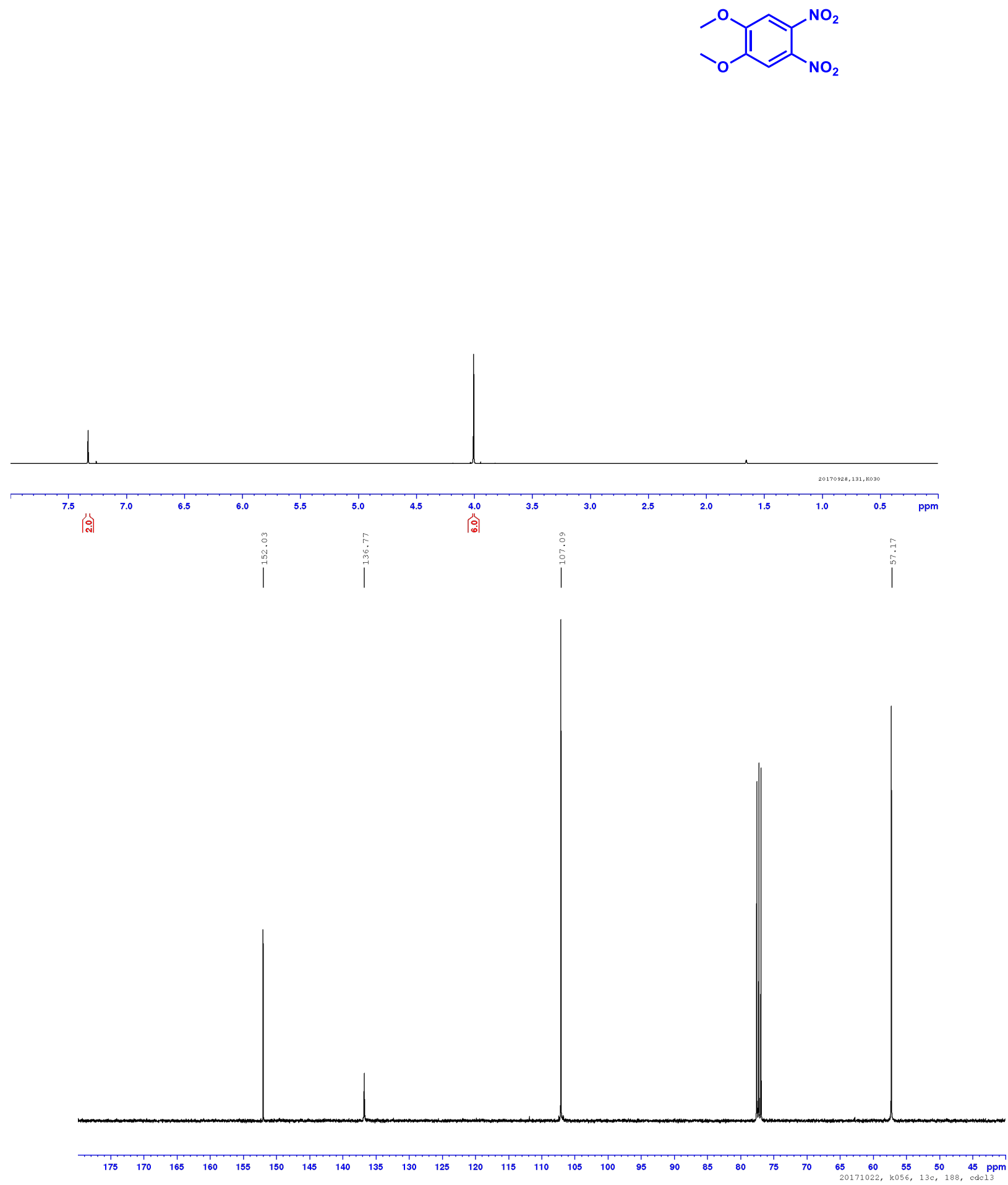
5,6-Dimethoxy-1H-benzo $[d]$ imidazole

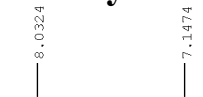

$\overbrace{}^{0} \overbrace{n}^{N}$
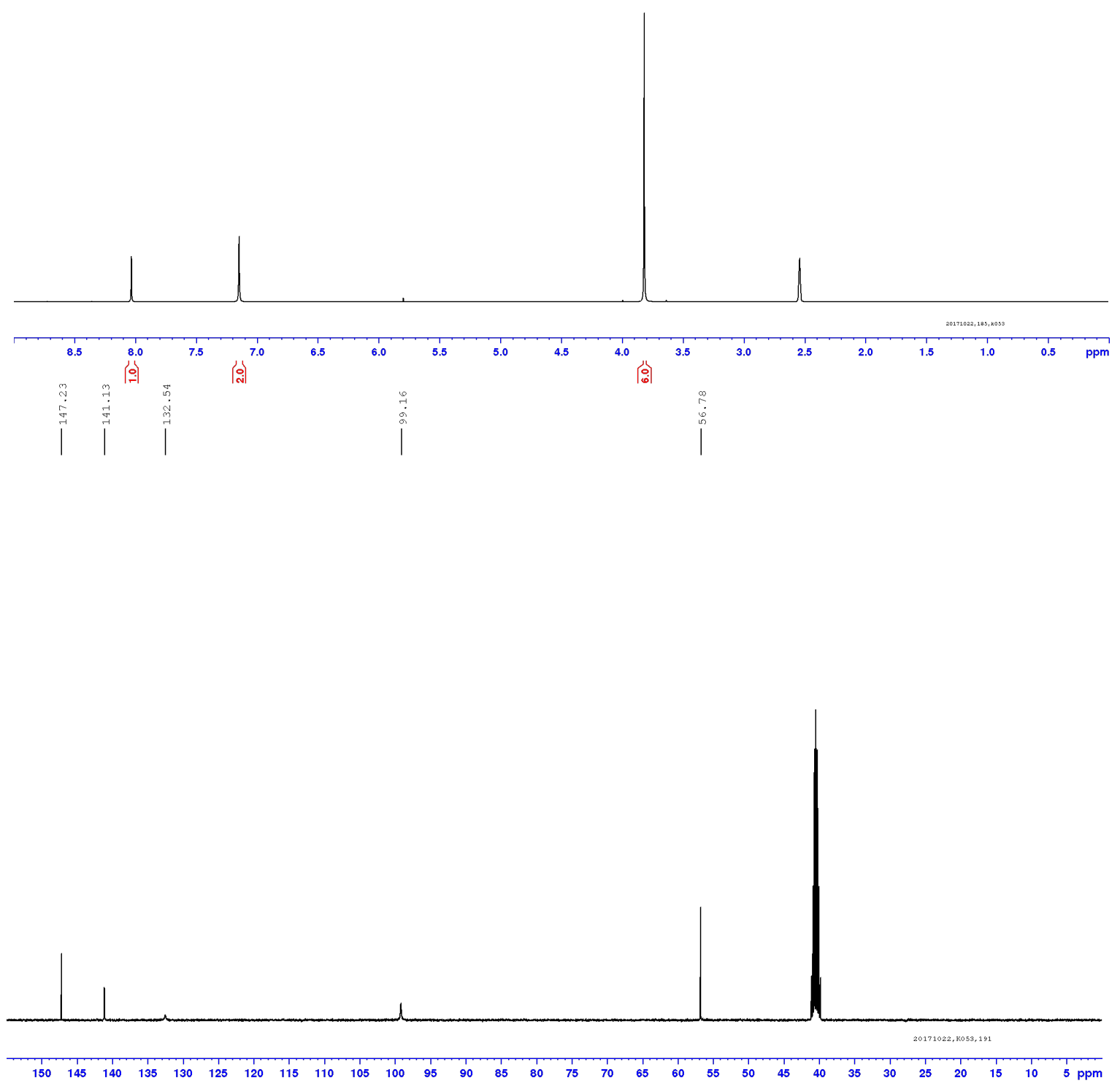
1H-Benzo $[d]$ imidazole-5,6-diol

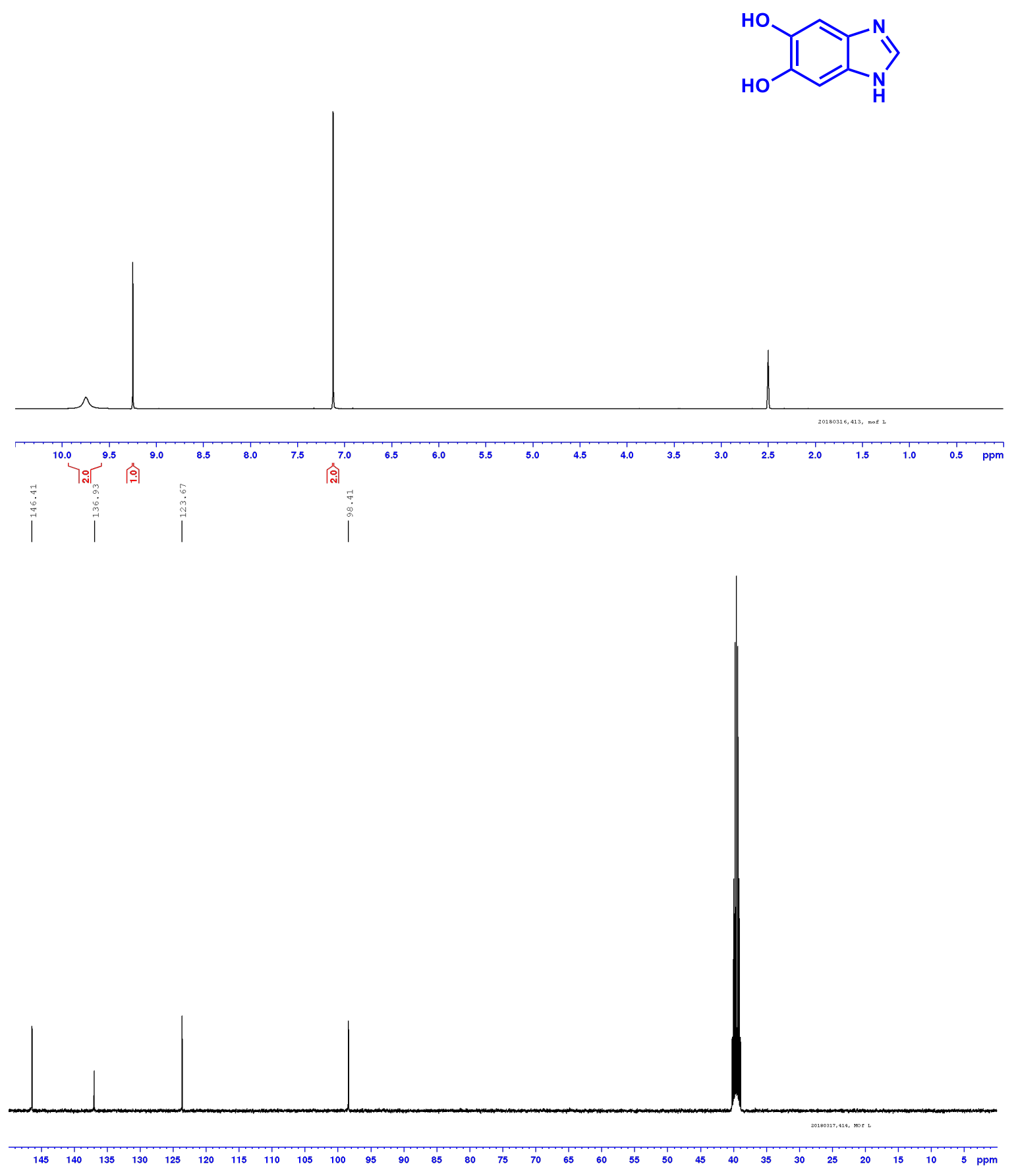




\section{5,6-Dimethyl-1H-benzo $[d]$ imidazole}

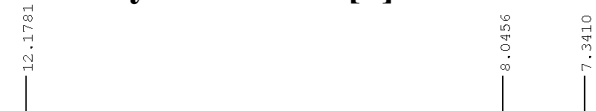

$$
\text { | }
$$
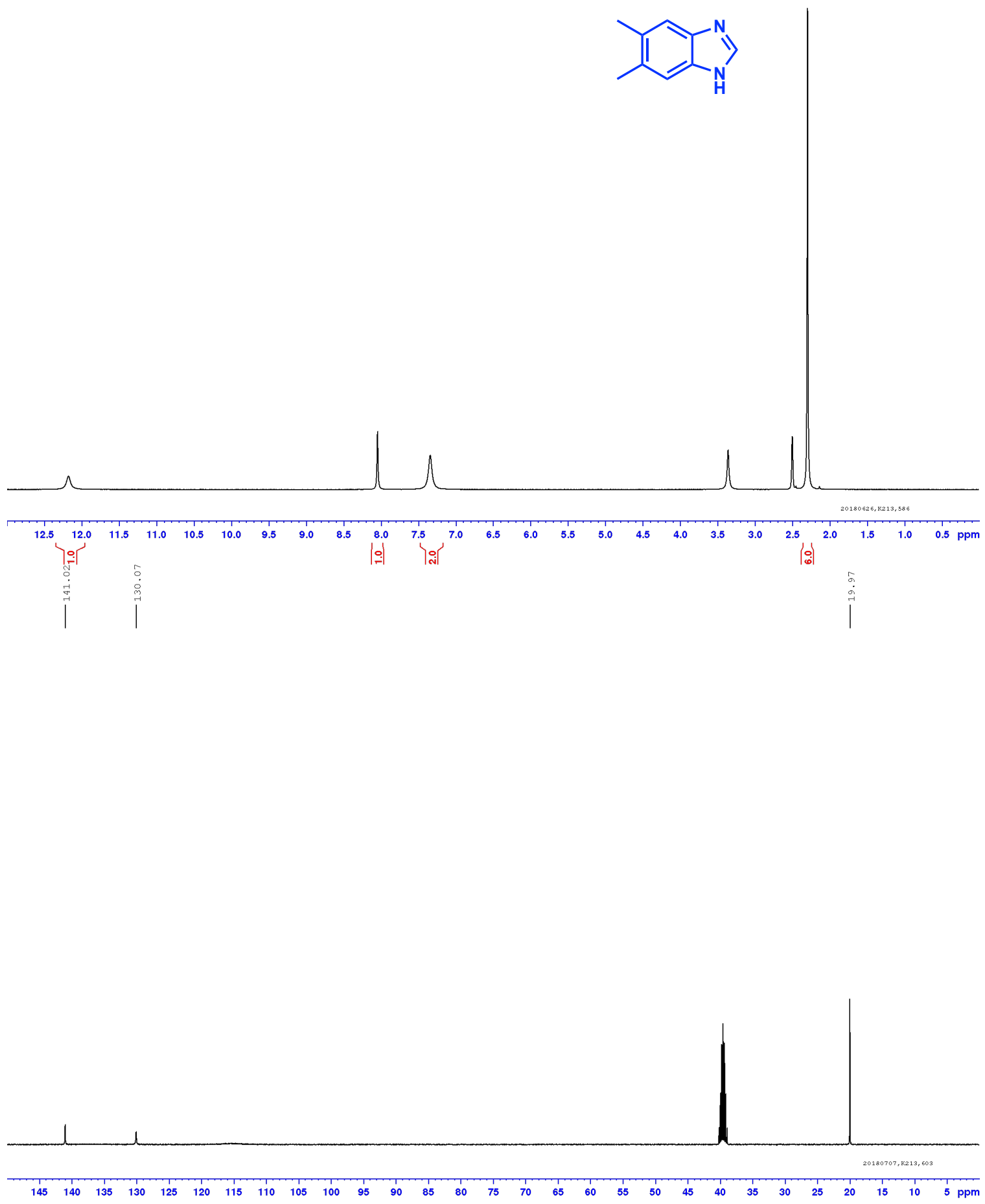
$1 H$-Benzo[d]imidazole-5,6-dicarboxylic acid<smiles>O=C(O)c1cc2nc[nH]c2cc1C(=O)O</smiles>

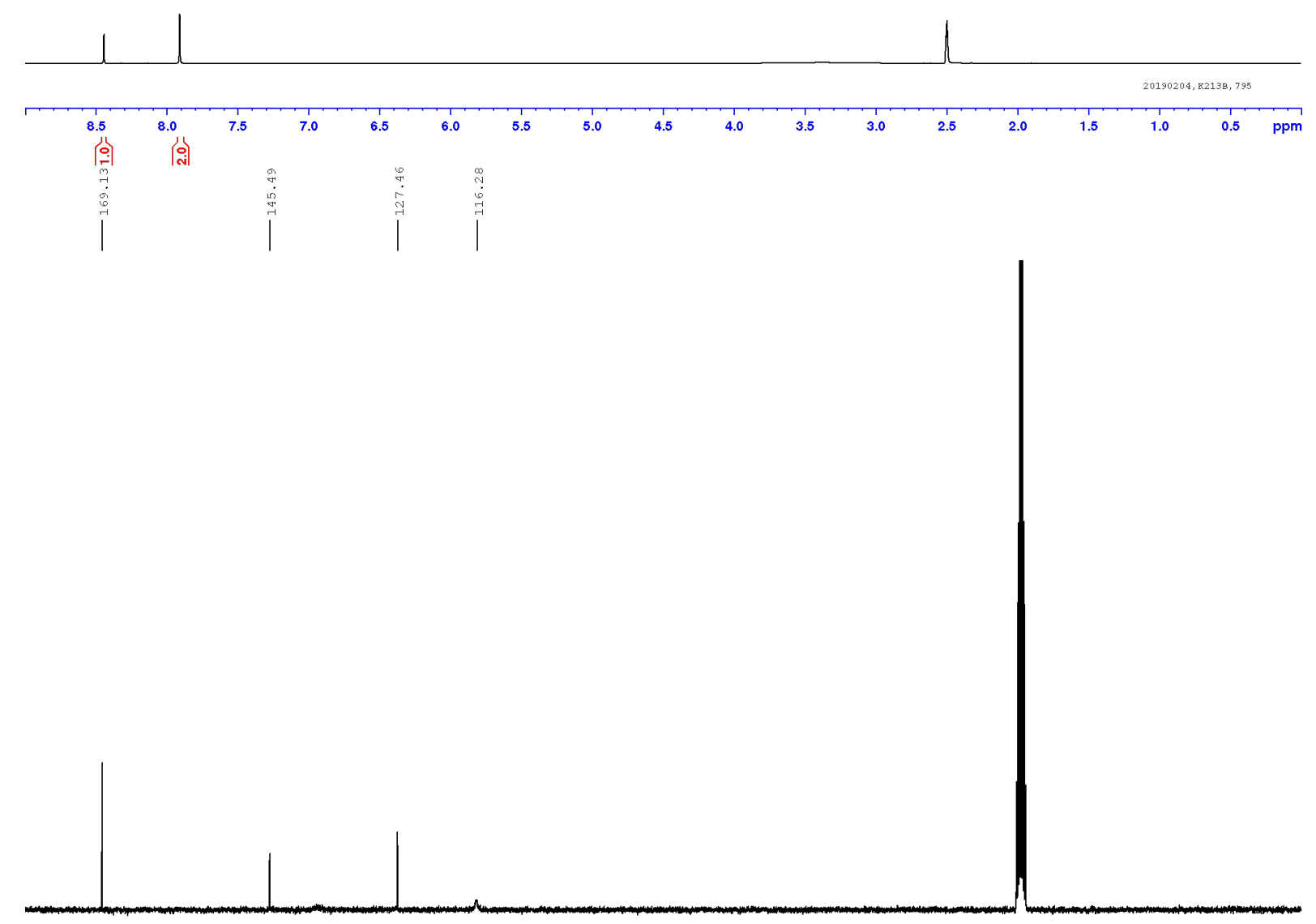

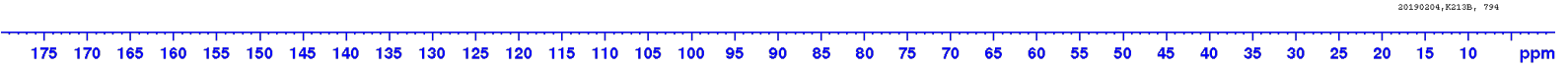

